\title{
Monetary policy transmission in India
}

\author{
Rakesh Mohan ${ }^{1}$
}

Key to the efficient conduct of monetary policy is the condition that it must exert a systematic influence on the economy in a forward-looking sense. A priori economic theory backed by some empirical evidence has identified the main channels through which monetary policy impacts its final targets, viz, output, employment and inflation. Broadly, the vehicles of monetary transmission can be classified into financial market prices (eg, interest rates, exchange rates, yields, asset prices, equity prices) or financial market quantities (money supply, credit aggregates, supply of government bonds and foreign denominated assets). It is recognized that, whereas these channels are not mutually exclusive, the relative importance of each channel may differ from one economy to another depending on a number of factors, including the underlying structural characteristics, the state of development of financial markets, the instruments available to monetary policy, the fiscal stance and the degree of openness.

Traditionally, four key channels of monetary policy transmission are identified, viz, interest rate, credit aggregates, asset prices and exchange rate channels. The interest rate channel emerges as the dominant transmission mechanism of monetary policy. An expansionary monetary policy, for instance, is expected to lead to a lowering of the cost of loanable funds, which, in turn, raises investment and consumption demand and should eventually be reflected in aggregate output and prices. Monetary policy also operates on aggregate demand through changes in the availability of loanable funds, ie, the credit channel. It is, however, relevant to note that the "credit channel" is not a distinct, free-standing alternative to the traditional transmission mechanism but should rather be seen as a channel that can amplify and propagate conventional interest rate effects (Bernanke and Gertler, 1995). Nevertheless, it is fair to regard the credit channel as running alongside the interest rate channel to produce monetary effects on real activity (RBI, 2002). Changes in interest rates by the monetary authorities also induce movements in asset prices to generate wealth effects in terms of market valuations of financial assets and liabilities. Higher interest rates can induce an appreciation of the domestic currency, which in turn leads to a reduction in net exports and, hence, in aggregate demand and output.

In the recent period, a fifth channel - expectations - has assumed prominence in the conduct of forward-looking monetary policy in view of its influence on the traditional four channels. For example, the link between short- and long-term real rates is widely believed to follow from the expectational hypothesis of the term structure of interest rates. In a generalized context, the expectations channel of monetary policy postulates that the beliefs of economic agents about future shocks to the economy as well as the central bank's reactions can affect the variables that are determined in a forward-looking manner. Thus, "open-mouth operation" by the central bank, ie, an announcement of future central bank policy, influences expectations in financial markets and leads to changes in output and inflation. Clearly, the credibility of the monetary authority drives the expectations channel.

The rest of the paper focuses on the Indian experience with monetary policy transmission. Section I delineates the objectives of monetary policy in India. Section II presents the framework and instruments of monetary policy alongside the evolution of institutional

1 Deputy Governor, Reserve Bank of India. The assistance of Michael D Patra and Sanjay Hansda in preparing this paper is gratefully acknowledged. 
developments which were to have a fundamental bearing on the monetary policy transmission. Section III discusses the monetary policy transmission channels: operating procedures, channel of bank lending and rates, debt market channel, exchange rate channel, and communication and expectations channel. Section IV makes an assessment of monetary transmission in terms of the ultimate objectives of monetary policy: price stability and growth. Section $V$ discusses what is needed to improve monetary transmission. In conclusion, Section VI sums up the challenges and dilemmas of monetary policy.

\section{Objectives of monetary policy}

The short title to the Reserve Bank of India Act, 1934 sets out the objectives of the Bank: "to regulate the issue of Bank notes and the keeping of reserves with a view to securing monetary stability in India and generally to operate the currency and credit system of the country to its advantage". Although there has not been any explicit legislation for price stability, the twin objectives of monetary policy in India are widely regarded as (i) price stability and (ii) provision of adequate credit to productive sectors of the economy so as to support aggregate demand and ensure high and sustained growth. With the increasing openness of the Indian economy, greater emphasis has been laid in recent years on strengthening the institutional capacity in the country to support growth consistent with stability in the medium term. Given the overarching consideration for sustained growth in the context of high levels of poverty and inequality, price stability has evolved as the dominant objective of monetary policy. The underlying philosophy is that it is only in a low and stable inflation environment that economic growth can be sustained.

In recent years, financial stability has assumed priority in the conduct of monetary policy in view of the increasing openness of the Indian economy, financial integration and possibility of cross border contagion. Strong synergies and complementarities are observed between price stability and financial stability in India. Accordingly, regulation, supervision and development of the financial system remain in India within the legitimate ambit of monetary policy, broadly interpreted.

\section{Framework and instruments}

Prior to the mid-1980s, there was no formal enunciation of monetary policy objectives, instruments and transmission channels in India other than that of administering the supply/allocation of and demand for credit in alignment with the needs of a planned economy. Over the period from 1985 to 1997, India followed a monetary policy framework that could broadly be characterised as one of loose and flexible monetary targeting with feedback (Annex I). Under this approach, growth in broad money supply (M3) was projected in a manner consistent with expected GDP growth and a tolerable level of inflation. The M3 growth thus worked out was considered a nominal anchor for policy. Reserve money (RM) was used as the operating target and bank reserves as the operating instrument. As deregulation increased the role of market forces in the determination of interest rates and the exchange rate, monetary targeting, even in its flexible mode, came under stress. Capital flows increased liquidity exogenously, putting upward pressure on the money supply, prices and the exchange rates, the latter having gained importance vis à vis quantity variables. While most studies in India showed that money demand functions had been fairly stable, it was increasingly felt that financial innovations and technology had systematically eroded the predictive potential of money demand estimations relative to the past. Interest rates gained relative influence on the decision to hold money. Accordingly, the monetary policy framework was reviewed towards the late 1990s, and the Reserve Bank switched over to a more broad- 
based multiple indicator approach from 1998-99. In this approach, policy perspectives are obtained by juxtaposing interest rates and other rates of return in different markets (money, capital and government securities markets), which are available at high frequency with medium and low frequency variables such as currency, credit extended by banks and financial institutions, the fiscal position, trade and capital flows, inflation rate, exchange rate, refinancing and transactions in foreign exchange and output. For simplicity and to facilitate greater understanding, the quarterly policy statements of the Reserve Bank continue to be set in a framework in terms of money, output and prices.

Since the late 1980s, there has been an enhanced emphasis by many central banks on securing operational freedom for monetary policy and investing it with a single goal, best embodied in the growing independence of central banks and inflation targeting as an operational framework for monetary policy, which has important implications for transmission channels. In this context, the specific features of the Indian economy have led to the emergence of a somewhat contrarian view: "In India, we have not favoured the adoption of inflation targeting, while keeping the attainment of low inflation as a central objective of monetary policy, along with that of high and sustained growth that is so important for a developing economy. Apart from the legitimate concern regarding growth as a key objective, there are other factors that suggest that inflation targeting may not be appropriate for India. First, unlike many other developing countries we have had a record of moderate inflation, with double digit inflation being the exception, and largely socially unacceptable. Second, adoption of inflation targeting requires the existence of an efficient monetary transmission mechanism through the operation of efficient financial markets and absence of interest rate distortions. In India, although the money market, government debt and forex markets have indeed developed in recent years, they still have some way to go, whereas the corporate debt market is still to develop. Though interest rate deregulation has largely been accomplished, some administered interest rates still persist. Third, inflationary pressures still often emanate from significant supply shocks related to the effect of the monsoon on agriculture, where monetary policy action may have little role. Finally, in an economy as large as that of India, with various regional differences, and continued existence of market imperfections in factor and product markets between regions, the choice of a universally acceptable measure of inflation is also difficult" (Mohan, 2006b).

The success of a framework that relies on indirect instruments of monetary management such as interest rates is contingent upon the extent and speed with which changes in the central bank's policy rate are transmitted to the spectrum of market interest rates and exchange rate in the economy and onward to the real sector. Clearly, monetary transmission cannot take place without efficient price discovery, particularly with respect to interest rates and exchange rates. Therefore, in the efficient functioning of financial markets, the corresponding development of the full financial market spectrum becomes necessary. In addition, the growing integration of the Indian economy with the rest of the world has to be recognized and provided for. Accordingly, reforms have been undertaken which focus on improving the operational effectiveness of monetary policy, while simultaneously strengthening the regulatory role of the Reserve Bank, tightening the prudential and supervisory norms, improving the credit delivery system and developing the technological and institutional framework of the financial sector.

\section{Market development}

Given the pivotal role of the money market in transmission, efforts initiated in the late 1980s were intensified over the full spectrum. Following the withdrawal of the ceiling on inter-bank money market rates in 1989, several financial innovations in terms of money market instruments such as certificate of deposits, commercial paper and money market mutual funds were introduced in phases. Barriers to entry were gradually eased by increasing the number of players and relaxing the issuance and subscription norms in respect of money market instruments, thus fostering better price discovery. Participation in the call money 
market was widened to cover primary and satellite dealers and corporates (through primary dealers), besides other participants. In order to improve monetary transmission, and also for prudential considerations, steps were initiated in 1999 to turn the call money market into a pure inter-bank market and, simultaneously, to develop a repo market outside the official window for providing a stable collateralised funding alternative, particularly to non-banks who were phased out of the call segment, and banks. The Collateralised Borrowing and Lending Obligation (CBLO), a repo instrument developed by the Clearing Corporation of India Limited (CCIL) for its members, with the CCIL acting as a central counterparty for borrowers and lenders, was permitted as a money market instrument in 2002. With the development of market repo and CBLO segments, the call money market has been transformed into a pure inter-bank market, including primary dealers, since August 2005. A recent noteworthy development is the substantial migration of money market activity from the uncollateralised call money segment to the collateralised market repo and CBLO markets (Annex II). Thus, uncollateralized overnight transactions are now limited to banks and primary dealers in the interests of financial stability (Table 1).

Table 1

\section{Activity in money market segments}

Rupees billion

\begin{tabular}{|c|c|c|c|c|c|c|}
\hline \multirow[b]{2}{*}{$\begin{array}{l}\text { Yearl } \\
\text { month }\end{array}$} & \multicolumn{4}{|c|}{ Average daily turnover (one leg) } & \multirow{2}{*}{$\begin{array}{c}\text { Commercial } \\
\text { paper } \\
\text { (outstanding) }\end{array}$} & \multirow{2}{*}{$\begin{array}{l}\text { Certificates } \\
\text { of deposit } \\
\text { (out- } \\
\text { standing) }\end{array}$} \\
\hline & $\begin{array}{l}\text { Call money } \\
\text { market }\end{array}$ & $\begin{array}{c}\text { Market } \\
\text { repo }\end{array}$ & CBLO & $\begin{array}{l}\text { Term } \\
\text { money } \\
\text { market }\end{array}$ & & \\
\hline 1 & 2 & 3 & 4 & 5 & 6 & 7 \\
\hline $2003-04^{1}$ & 86 & 26 & 3 & 3 & 78 & 32 \\
\hline $2004-05^{1}$ & 71 & 43 & 34 & 3 & 117 & 61 \\
\hline $2005-06^{1}$ & 90 & 53 & 100 & 4 & 173 & 273 \\
\hline \multicolumn{7}{|l|}{$2006-07$} \\
\hline April & 85 & 55 & 163 & 5 & 165 & 441 \\
\hline May & 90 & 90 & 172 & 5 & 169 & 502 \\
\hline June & 87 & 106 & 138 & 6 & 197 & 564 \\
\hline July & 91 & 97 & 157 & 4 & 211 & 592 \\
\hline August & 107 & 78 & 156 & 5 & 229 & 656 \\
\hline September & 118 & 92 & 148 & 6 & 244 & 653 \\
\hline October & 132 & 97 & 170 & 5 & 232 & 658 \\
\hline November & 128 & 94 & 161 & 4 & 242 & 689 \\
\hline December & 121 & 72 & 155 & 5 & 233 & 686 \\
\hline
\end{tabular}

CBLO: Collateralised borrowing and lending obligation.

1 The average daily turnover (one leg) for a year is arrived at by adding daily turnovers (one leg) and then dividing the sum by the number of days in the year.

Source: Macroeconomic and Monetary Developments, various issues, RBI.

The Government securities market is important for the entire debt market as it serves as a benchmark for pricing other debt market instruments, thereby aiding the monetary 
transmission across the yield curve. The key policy development that has enabled a more independent monetary policy environment as well as the development of the Government securities market was the discontinuation of automatic monetization of the government's fiscal deficit since April 1997 through an agreement between the Government and the Reserve Bank of India in September 1994 (Annex III). Subsequently, enactment of the Fiscal Responsibility and Budget Management Act, 2003 has strengthened the institutional mechanism further: from April 2006 onwards, the Reserve Bank is no longer permitted to subscribe to government securities in the primary market. This step completes the transition to a fully market-based system for Government securities. Looking ahead, consequent to the recommendations of the Twelfth Finance Commission, the Central Government would cease to raise resources on behalf of State Governments, which, henceforth, will have to access the market directly. Thus, State Governments' ability to raise resources will be marketdetermined and based on their own financial health. To ensure a smooth transition, institutional processes are being revamped towards greater integration in monetary operations.

As regards the foreign exchange market, reforms have been focused on market development, incorporating prudential safeguards so that the market would not be destabilised in the process. The move towards a market-based exchange rate regime in 1993, the subsequent adoption of current account convertibility and de-facto capital account convertibility for select categories of non-residents were the key enabling factors in reforming the Indian foreign exchange market prior to now. India's approach to financial integration has so far been gradual and cautious, guided by signposts/concomitants in terms of improvement in fiscal, inflation and financial sector indicators, inter alia. Efforts are currently underway to move towards fuller capital account convertibility even for residents. In the period 2000-06, a number of measures were initiated to integrate the Indian forex market with the global financial system, with increasing freedom given to banks to borrow abroad and fix their own position and gap limits (Annex IV).

The development of the monetary policy framework has also involved a great deal of institutional initiatives in the area of trading, payments and settlement systems along with the provision of technological infrastructure. The interaction of technology with deregulation has also contributed to the emergence of a more open, competitive and globalised financial market. While the policy measures in the pre-1990s period were essentially devoted to financial deepening, the focus of reforms in the last decade and a half has been on engendering greater efficiency and productivity in the banking system (Annex $\mathrm{V}$ ). Legislative amendments have also been carried out to strengthen the RBI's regulatory jurisdiction over financial markets, providing greater instrument independence and, hence, ensuring monetary transmission.

The relative weights assigned to various channels of transmission of monetary policy also reflect a conscious effort to move from direct instruments of monetary control to indirect instruments. Illustratively, the CRR, which had been brought down from a peak of 15 per cent in 1994-95 to 4.5 per cent by June 2003, before the onset of withdrawal of monetary accommodation, since October 2004 is now 6.0 per cent (Chart 1 ). The recent amendment to the RBI Act in 2006 will further strengthen monetary maneuverability since it allows for the removal of the floor of 3 per cent and ceiling of 15 per cent on the CRR. Monetary control is also exercised through the prescription of a statutory liquidity ratio (SLR), which is a variant of the secondary reserve requirement in several countries. It is maintained in the form of specified assets such as cash, gold and "approved" and unencumbered securities - the latter being explicitly prescribed - as a proportion of banks' net demand and time liabilities (NDTL). Accordingly, the SLR is also important for prudential purposes, ie, to assure the soundness of the banking system. The pre-emption under the SLR, which had increased to about 38.5 per cent of NDTL in the beginning of the 1990s, was brought to its statutory minimum of 25 per cent by October 1997. Banks, however, continue to hold more government securities than the statutory minimum SLR, reflecting risk perception and portfolio choice. The statutory 
minimum SLR of 25 per cent has been removed now (January 2007) to provide for greater flexibility in the RBI's monetary policy operations. The reform of the monetary and financial sectors has thus enabled the Reserve Bank to expand the array of instruments at its command and enhanced its ability to respond to evolving circumstances.

Chart 1

\section{Reserve requirements}

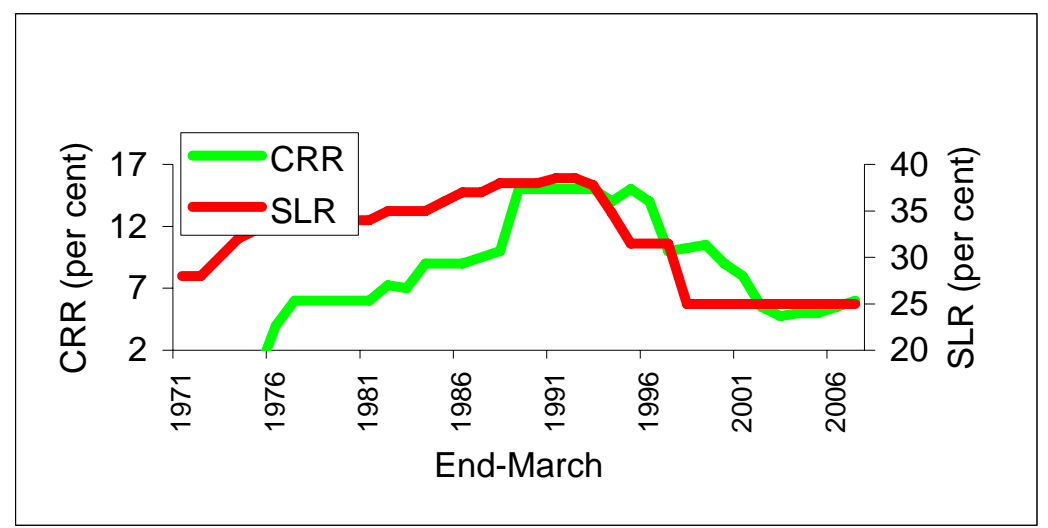

\section{Operating procedure for monetary policy}

Short-term interest rates have emerged as the key indicators of the monetary policy stance all over the world. It is also recognised that stability in financial markets is critical for efficient price discovery and meaningful signaling. Since the interest rate and exchange rate are key prices reflecting the cost of money, it is particularly important for efficient functioning of the economy that they be market-determined and easily observed.

Central banks follow a variety of operating frameworks and procedures for signaling and implementing the monetary policy stance on a day-to-day basis, with a view to achieving the ultimate objectives - price stability and growth. The choice of policy framework in any economy is always a difficult one and depends on the stage of macro-economic and financial sector development, and is somewhat of an evolutionary process (Mohan, 2006a). In a market-oriented financial system, central banks typically use instruments that are directly under their control: required reserve ratios, interest charged on borrowed reserves (discount window) provided directly or through rediscounting of financial assets held by depository institutions, open market operations (OMOs) and selective credit controls. These instruments are usually directed at attaining a prescribed value of the operating target, typically bank reserves and/or a very short-term interest rate (usually the overnight interbank rate). The optimal choice between price and quantity targets would depend on the sources of disturbances in the goods and money markets (Poole, 1970). If money demand is viewed as highly unstable, greater output stability can be attained by stabilizing interest rates. If, however, the main source of short-run instability arises from aggregate spending or unsterilized capital inflows, a policy that stabilizes monetary aggregates could be desirable. In reality, it often becomes difficult to trace out the sources of instability. Instead, monetary policy is implemented by fixing, at least over the short time horizon, the value of an operating target or policy instrument. As additional information about the economy is obtained, the appropriate level at which to fix the policy instrument/target changes.

The operating procedures of monetary policy of most central banks have largely converged to one of the following three variants: (i) a number of central banks, including the US Federal Reserve, estimate the demand for bank reserves and then carry out open market operations to target short-term interest rates; (ii) another set of central banks, of which the Bank of 
Japan used to be a part until recently, estimate market liquidity and carry out open market operations to target bank reserves, while allowing interest rates to adjust; and (iii) a growing number of central banks, including the European Central Bank and the Bank of England, modulate monetary conditions in terms of both quantum and price of liquidity, through a mix of OMOs, standing facilities and minimum reserve requirements, and changes in the policy rate. The operating procedure followed in India, however, presents a fourth variant.

\section{III.1 Money markets and the liquidity adjustment facility}

In the Indian context, reforms in the monetary policy operating framework, which were initiated in the late 1980s, crystallised into the Liquidity Adjustment Facility (LAF) in 2000 (Annex VI). Under the LAF, the Reserve Bank sets its policy rates, ie, repo and reverse repo rates, and carries out repo/reverse repo operations, thereby providing a corridor for overnight money market rates (Chart 2). The LAF avoids targeting a particular level of overnight money market rate in view of exogenous influences impacting liquidity at the shorter end, viz, volatile government cash balances and unpredictable foreign exchange flows.

Although repo auctions can be conducted at variable or fixed rates for overnight or longerterm, given market preference and the need to transmit interest rate signals quickly, the LAF has settled into a fixed rate overnight auction mode since April 2004. With the introduction of Second LAF (SLAF) from November 28, 2005, market participants now have a second window during the day to fine-tune their liquidity management (Chart 3). LAF operations continue to be supplemented by access to the Reserve Bank's standing facilities linked to repo rate: export credit refinance to banks and standing liquidity facility to the primary dealers.

\section{Chart 2}

\section{Liquidity adjustment facility and money market instruments for liquidity management}

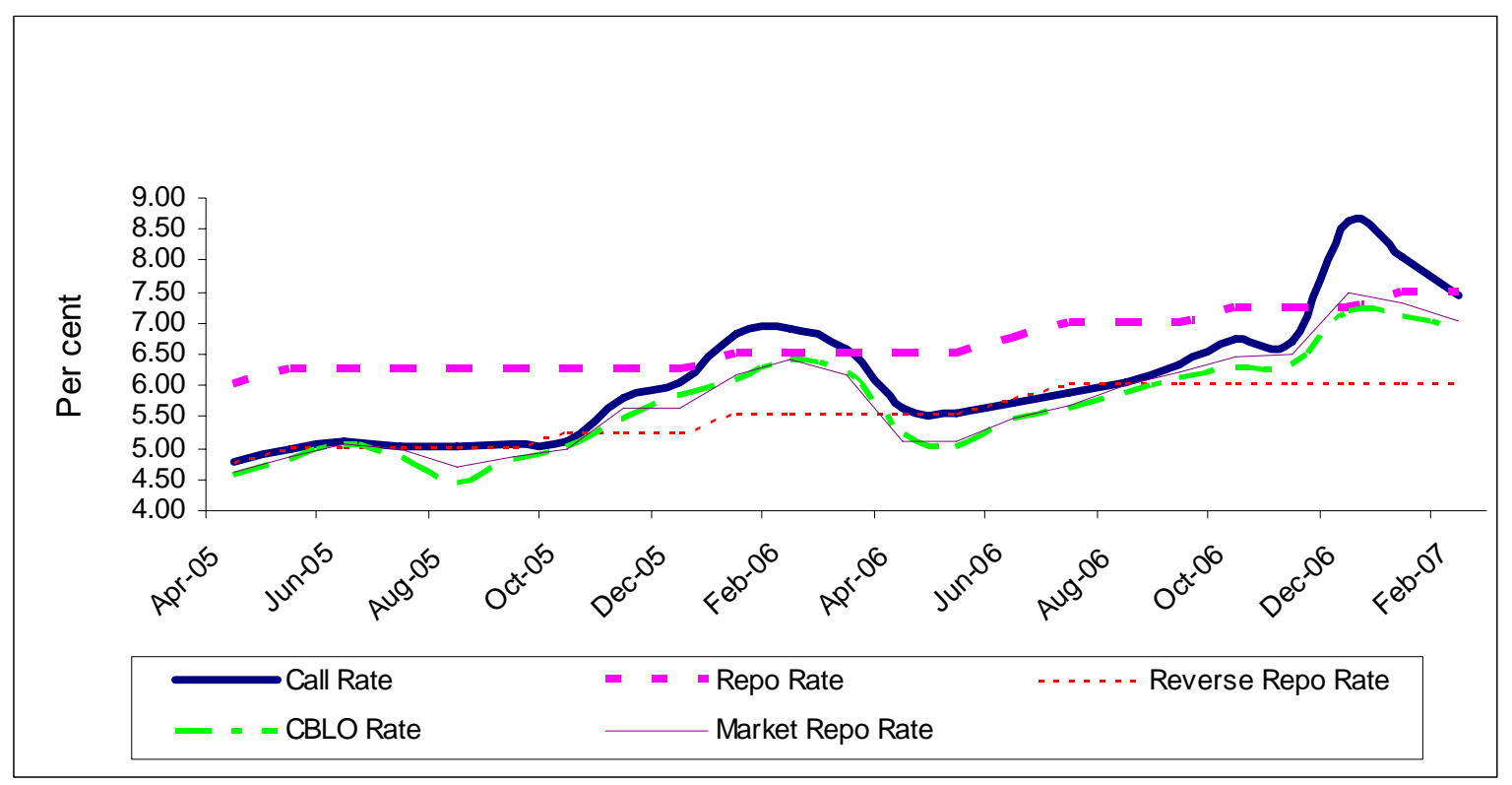

The introduction of LAF has had several advantages. First and foremost, it made possible the transition from direct instruments of monetary control to indirect instruments. Since LAF operations enabled reduction in CRR without loss of monetary control, certain dead weight loss for the system was saved. Second, LAF has provided monetary authorities with greater flexibility in determining both the quantum of adjustment and the rates by responding to the 
needs of the system on a daily basis. Third and most importantly, although there is no formal targeting of a point overnight interest rate, LAF helped to stabilise overnight call rates within a specified corridor, the difference between the fixed repo and reverse repo rates currently being 150 basis points. It has thus enabled the central bank to affect demand for funds through policy rate changes. In this sense, LAF rates perform the role of nominal anchor effectively. Although call money rates edged above the repo rate in January-February 2006, the rates in the collateralised segment of the money market - market repos and Collateralised Borrowing and Lending Obligations (CBLO), which account for nearly 80 per cent of the market turnover - remained below the repo rate.

\section{Chart 3}

\section{Repo (+)/ reverse repo (-) under LAF}

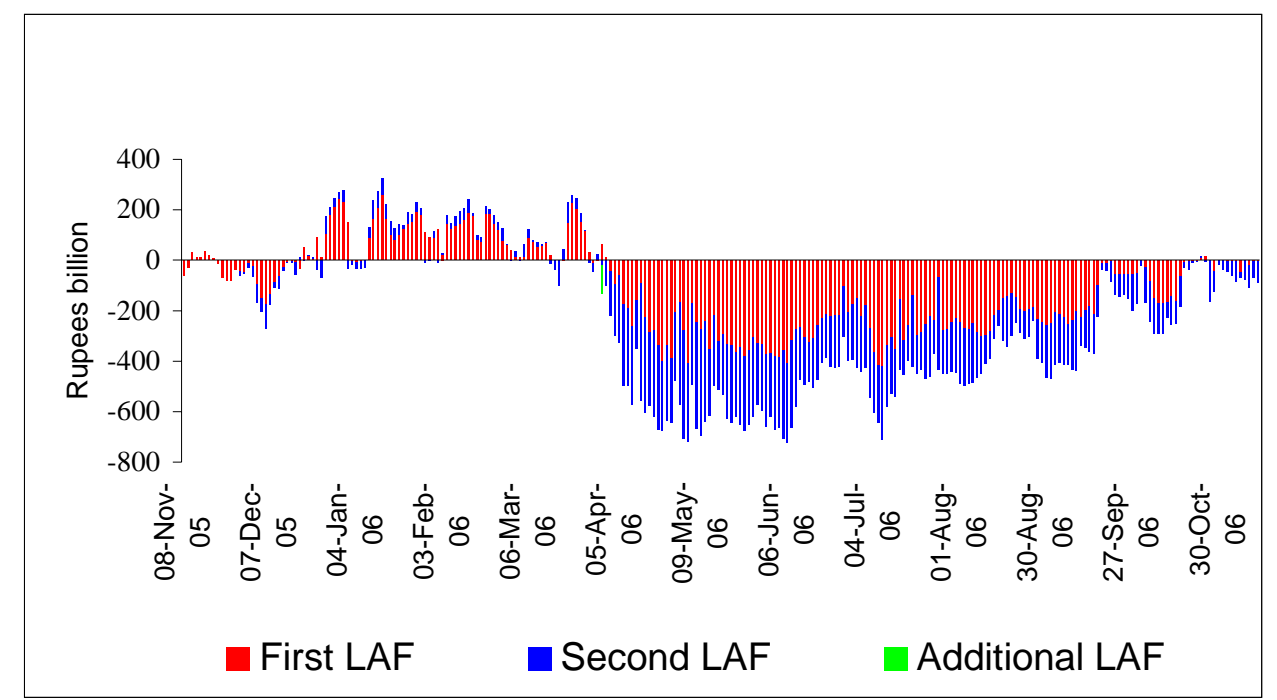

\section{III.2 Market stabilisation scheme}

In the context of increasing openness of the economy, a market-determined exchange rate and large capital inflows, monetary management may warrant sterilizing foreign exchange market intervention, partly or wholly, so as to retain the intent of monetary policy. Initially, the Reserve Bank sterilized capital inflows by way of OMOs. Such sterilization, however, involves cost in terms of lower returns on international assets vis-à-vis domestic assets (Chart 4). The finite stock of government securities with the Reserve Bank also limited its ability to sterilize. The LAF operations, which are essentially designed to take care of frictional daily liquidity, began to bear the burden of stabilization disproportionately. 
Chart 4

Changes in net domestic assets and net foreign assets

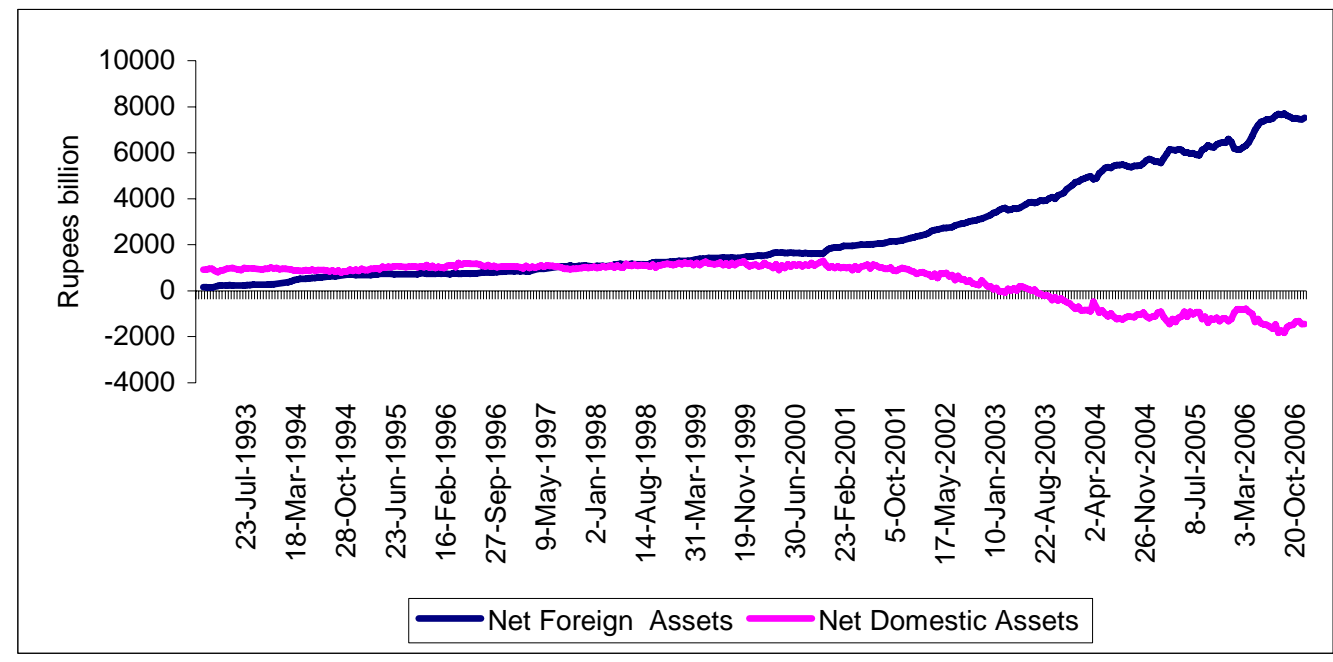

The Reserve Bank, therefore, signed in March 2004 a Memorandum of Understanding (MoU) with the Government of India for issuance of Treasury Bills and dated Government Securities under the Market Stabilisation Scheme (MSS), in addition to normal Government borrowings (Annex VII). The new instrument empowered the Reserve Bank to absorb liquidity on a more enduring but still temporary basis while leaving LAF for daily liquidity management and using conventional OMO on a more enduring basis (Chart 5). The MSS has provided the Reserve Bank with the flexibility not only to absorb but also to inject liquidity in times of need by way of unwinding. Therefore, short-term instruments are generally preferred for MSS operations.

Chart 5

\section{Liquidity management}

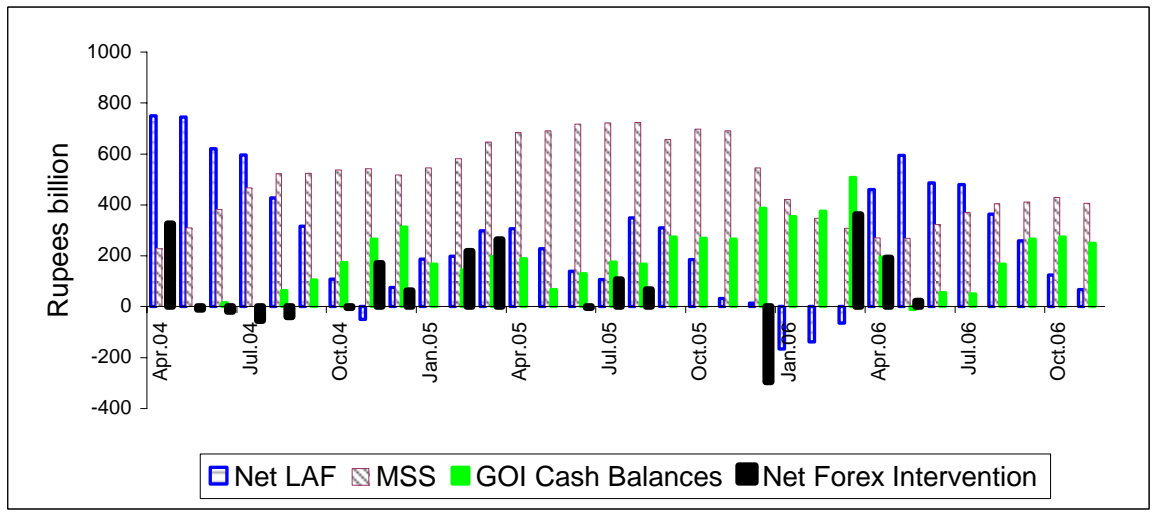

The various tools of liquidity management have thus enabled the Reserve Bank to maintain liquidity conditions and orderly movement in both exchange rates and interest rates, and conduct monetary policy in accordance with its stated objectives (Annex VIII and Table 2). 
Table 2

Phases of Reserve Bank's liquidity management operations

Rupees billion

\begin{tabular}{|c|c|c|c|c|c|c|}
\hline \multirow{2}{*}{\multicolumn{2}{|c|}{ Item }} & \multicolumn{5}{|c|}{ Variation during } \\
\hline & & 2003-04 & 2004-05 & $2005-06$ & $\begin{array}{c}2006-07 \\
\text { Q1 }\end{array}$ & $\begin{array}{c}2006-07 \\
\text { Q2 }\end{array}$ \\
\hline & 1 & 2 & 3 & 4 & 5 & 6 \\
\hline A. & Drivers of liquidity $(1+2+3+4)$ & 721 & 581 & -317 & 355 & -158 \\
\hline 1. & $\begin{array}{l}\text { RBI's foreign currency assets (adjusted } \\
\text { for revaluation) }\end{array}$ & 1414 & 1150 & 688 & 285 & 105 \\
\hline 2. & Currency with the Public & -434 & -409 & -573 & -215 & -1 \\
\hline 3. & $\begin{array}{l}\text { Surplus cash balances of the centre with } \\
\text { the Reserve Bank }\end{array}$ & -177 & 5 & -227 & 402 & -262 \\
\hline 4. & Others (residual) & -83 & -165 & -205 & -118 & -1 \\
\hline B. & Management of liquidity $(5+6+7+8)$ & -464 & -567 & 580 & -390 & 320 \\
\hline 5. & Liquidity impact of LAF Repos & -322 & 153 & 121 & -353 & 407 \\
\hline 6. & Liquidity impact of OMO (Net) ${ }^{1}$ & -176 & 12 & 107 & 5 & 1 \\
\hline 7. & Liquidity impact of MSS & 0 & -642 & 351 & -42 & -88 \\
\hline 8. & $\begin{array}{l}\text { First round liquidity impact due to CRR } \\
\text { change }\end{array}$ & 35 & -90 & 0 & 0 & 0 \\
\hline c. & Bank Reserves $(A+B)^{2}$ & 257 & 14 & 263 & -35 & 162 \\
\hline
\end{tabular}

Note: Data pertain to March 31 and last Friday for all other months.

(+) Indicates injection of liquidity into the banking system. (-) Indicates absorption of liquidity from the banking system.

1 Adjusted for Consolidated Sinking Funds (CSF) and Other Investments and including private placement.

2 Includes vault cash with banks and adjusted for first round liquidity impact due to CRR change.

Source: Annual Report and Macroeconomic and Monetary Developments, various issues, RBI.

Government cash balances with the Reserve Bank often display sizeable volatility. First, due to operational requirements which are difficult to predict (except for salary payments, coupon/interest payments, redemption of loans and the like), the Government needs to maintain a substantial cash position with the Reserve Bank. Second, there is the need for maintaining or building up cash balances gradually over many weeks ahead of large, known disbursements such as lumpy redemption of bonds contracted for financing high fiscal deficit and, particularly, benchmark bonds, if markets are not to be disrupted. Third, while a major part of outflows from government cash balances is regular, inflows by way of direct tax revenues and other sources are lumpy and irregular in nature.

Accumulating Government cash balances with the central bank act, in effect, as withdrawal of liquidity from the system and have the same effect as that of monetary tightening, albeit without any intention to do so by the monetary authority. Similarly, there would be injection of liquidity into the system if Government cash balances maintained with the central bank decline, despite a situation in which, for instance, monetary policy is biased towards tightening liquidity. Thus, volatile Government cash balances could cause unanticipated expansion or contraction of the monetary base, and consequently, money supply and 
liquidity, which may not necessarily be consistent with the prevailing stance of monetary policy. In the presence of fluctuating Government cash balances, the task of monetary management becomes complicated, often warranting offsetting measures, partly or wholly, so as to retain the intent of monetary policy.

\section{III.3 Bank credit and lending rate channels}

There is some evidence of the bank lending channel working in addition to the conventional interest rate channel. In view of the asymmetry in the resource base, access to non-deposit sources, asset allocation and liquidity, big and small banks are found to respond in significantly different ways. In particular, small banks are more acutely affected by contractionary monetary policy shocks as compared to big banks, ie, smaller banks curtail their lending more sharply vis-à-vis large banks (Pandit et al, 2006). Available empirical evidence also indicates that prudential norms, as proxied by banks' capital adequacy ratios, exert a significant influence on bank lending (Annex IX, Nag and Das, 2002; Pandit et al, 2006).

Table 3

\section{Sectoral shares in non-food bank credit}

Per cent

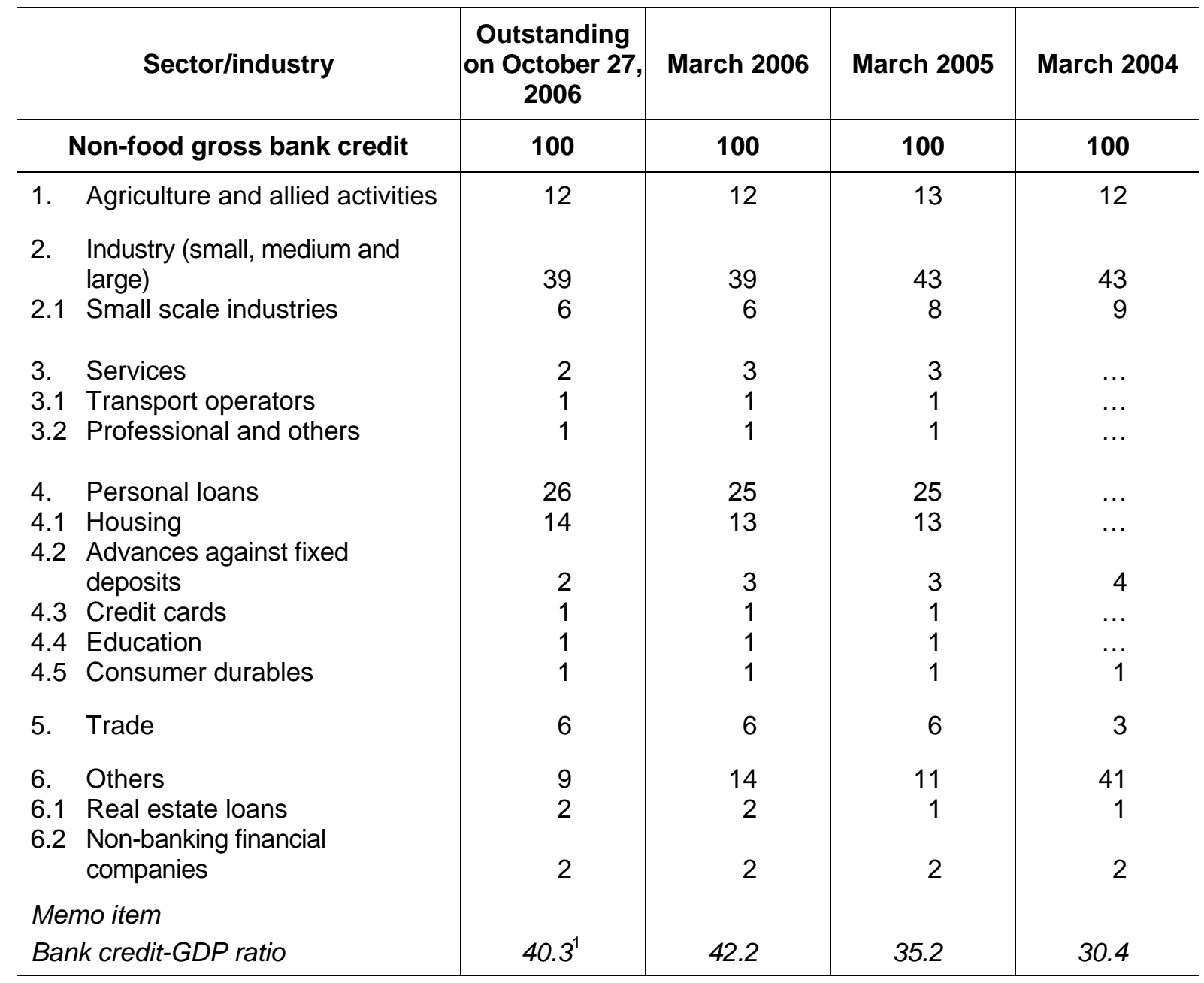

Note: Sectoral shares may not add up to 100 due to rounding off.

1 Approximately.

Source: Annual Report 2005-06, RBI. 
The monetary policy stance of the Bank is often articulated as a commitment to ensure that all genuine requirements for bank credit are adequately met in order to support investment and export demand consistent with price stability (Annex $\mathrm{X}$ ). Liquidity operations are conducted with a view to ensuring that the demand for reserves is satisfied and credit projections consistent with macro-economic objectives are achieved. Simultaneously, improvements in the delivery of bank credit are pursued in recognition of the possibility of market failure in efficiently auctioning credit. An integral element of the conduct of monetary policy has, therefore, been the direction of bank credit to certain sectors of priority such as agriculture, exports, small scale industry, infrastructure, housing, micro-credit institutions and self-help groups. An ongoing policy endeavour is enhancing and simplifying the access to credit with a view to securing the widest inclusion of society in the credit market (Table 3).

Available empirical evidence covering the period September 1998-March 2004 suggests that the interest rate pass-through from changes in the policy rate was 0.61 and 0.42 for lending and deposit rates, respectively, ie, a reduction/increase of 100 basis points (bps) in the Bank Rate led to a reduction/increase of almost 40 bps in the banks' deposit rates and $60 \mathrm{bps}$ in their prime lending rate (Tables $4 \& 5$ ). Rolling regressions suggest some improvement in pass-through to lending rates and deposits. Thus, although pass-through is less than complete, there are signs of an increase in pass-through over time (RBI, 2004b).

\section{Table 4}

\section{Outstanding term deposits of scheduled commercial banks by interest rate}

At the end of March

Per cent to total deposits

\begin{tabular}{l|c|c|c|r|r|r|r|r|r|c}
\hline $\begin{array}{c}\text { Interest } \\
\text { Rate Slab }\end{array}$ & $\mathbf{1 9 9 6}$ & $\mathbf{1 9 9 7}$ & $\mathbf{1 9 9 8}$ & $\mathbf{1 9 9 9}$ & $\mathbf{2 0 0 0}$ & $\mathbf{2 0 0 1}$ & $\mathbf{2 0 0 2}$ & $\mathbf{2 0 0 3}$ & $\mathbf{2 0 0 4}$ & $\mathbf{2 0 0 5}$ \\
\hline \multicolumn{1}{c|}{$\mathbf{1}$} & \multicolumn{1}{c|}{$\mathbf{2}$} & $\mathbf{3}$ & \multicolumn{1}{c|}{$\mathbf{4}$} & $\mathbf{5}$ & $\mathbf{6}$ & $\mathbf{7}$ & $\mathbf{8}$ & $\mathbf{9}$ & $\mathbf{1 0}$ & $\mathbf{1 1}$ \\
\hline$<8 \%$ & 10.8 & 11.2 & 11.5 & 13.3 & 16.8 & 16.9 & 25.0 & 53.7 & 74.0 & 86.4 \\
$8-9 \%$ & 2.4 & 5.2 & 4.8 & 6.1 & 6.5 & 10.5 & 22.6 & 16.4 & 9.9 & 5.8 \\
$9-10 \%$ & 4.5 & 7.1 & 6.4 & 9.0 & 14.3 & 16.1 & 19.8 & 12.0 & 7.3 & 3.1 \\
$10-11 \%$ & 15.2 & 14.1 & 13.7 & 17.7 & 20.9 & 23.9 & 17.3 & 10.5 & 5.1 & 2.5 \\
$11-12 \%$ & 13.9 & 14.3 & 16.3 & 20.2 & 19.2 & 17.9 & 9.1 & 4.5 & 2.3 & 1.1 \\
$12-13 \%$ & 23.4 & 20.9 & 22.3 & 19.2 & 13.9 & 9.1 & 4.3 & 2.3 & 1.1 & 0.5 \\
$>13 \%$ & 29.8 & 27.2 & 25.0 & 14.5 & 8.4 & 5.6 & 1.9 & 0.8 & 0.5 & 0.7 \\
\hline
\end{tabular}

Source: Basic Statistical Returns of Scheduled Commercial Banks in India, various issues, Reserve Bank of India. 
Table 5

\section{Outstanding loans of scheduled commercial banks by interest rate}

At the end of March

Per cent to total loans

\begin{tabular}{l|c|c|c|c|c|c|c|c|c|c|c}
\hline $\begin{array}{c}\text { Interest } \\
\text { Rate Slab }\end{array}$ & $\mathbf{1 9 9 0}$ & $\mathbf{1 9 9 5}$ & $\mathbf{1 9 9 7}$ & $\mathbf{1 9 9 8}$ & $\mathbf{1 9 9 9}$ & $\mathbf{2 0 0 0}$ & $\mathbf{2 0 0 1}$ & $\mathbf{2 0 0 2}$ & $\mathbf{2 0 0 3}$ & $\mathbf{2 0 0 4}$ & $\mathbf{2 0 0 5}$ \\
\hline \multicolumn{1}{c|}{$\mathbf{1}$} & \multicolumn{1}{c|}{$\mathbf{2}$} & \multicolumn{1}{c|}{$\mathbf{3}$} & \multicolumn{1}{c|}{$\mathbf{4}$} & \multicolumn{1}{c|}{$\mathbf{5}$} & \multicolumn{1}{c}{$\mathbf{6}$} & \multicolumn{1}{c}{$\mathbf{7}$} & $\mathbf{8}$ & $\mathbf{9}$ & $\mathbf{1 0}$ & $\mathbf{1 1}$ & $\mathbf{1 2}$ \\
\hline$<6 \%$ & 2.7 & 2.3 & 1.1 & 1.0 & 0.3 & 0.2 & 0.2 & 0.1 & 0.1 & 0.4 & 0.4 \\
$6-10 \%$ & 6.8 & 2.1 & 0.5 & 0.4 & 3.7 & 1.0 & 0.6 & 3.2 & 5.3 & 13.6 & 19.5 \\
$10-12 \%$ & 4.8 & 2.3 & 1.4 & 2.3 & 3.3 & 7.9 & 17.0 & 24.5 & 22.9 & 16.1 & 17.5 \\
$12-14 \%$ & 21.4 & 10.6 & 10.7 & 13.2 & 20.3 & 26.8 & 28.6 & 22.5 & 25.1 & 25.7 & 22.4 \\
$14-15 \%$ & 4.4 & 6.7 & 10.9 & 14.9 & 9.7 & 11.5 & 12.6 & 14.1 & 19.4 & 16.2 & 16.6 \\
$>15 \%$ & 59.8 & 76.0 & 75.4 & 68.2 & 62.7 & 52.6 & 41.0 & 35.6 & 27.1 & 28.0 & 23.6 \\
\hline
\end{tabular}

Source: As in Table 4.

The improvement in the pass-through can be attributed to policy efforts to impart greater flexibility to the interest rate structure in the economy through various measures such as advising banks to: introduce a flexible interest rate option for new deposits; review their maximum spreads over the prime lending rate (PLR) and reduce them wherever they are unreasonably high; announce the maximum spread over PLR to the public along with the announcement of the PLR; and switch over to an "all cost" concept for borrowers by explicitly declaring the various charges such as processing and service charges (Table 6). ${ }^{2}$ Besides, interest rates have emerged as a more potent instrument than before with the move towards floating, as against fixed rate products, under which the transmission is limited at the margin.

2 From October 18, 1994, banks have been free to fix the lending rates for loans above Rupees 200,000. Banks were required to obtain the approval of their respective Boards for the PLR which would be the minimum rate charged for loans above Rupees 2,00,000. In the interest of small borrowers, as well as to remove the disincentive for credit flow to such borrowers, the PLR was converted into a ceiling rate for loans up to Rupees $2,00,000$ in 1998-99. Sub-PLR lending was allowed in 2001-02 in keeping with international practice. For customers' protection and meaningful competition, bank-wise quarterly data on the PLR, along with maximum and minimum lending rates, have been placed on the Reserve Bank's website, starting from June 2002. To encourage greater transparency in loan pricing in the context of sticky behaviour of lending rates, the system of BPLR (ie, benchmark PLR) was introduced in 2003-04. Banks were advised to specify their BPLR taking into account (a) the actual cost of funds, (b) operating expenses and (c) a minimum margin to cover regulatory requirements of provisioning and capital charges, and profit margin. Whereas conceptually the BPLR should turn out to be a median lending rate, in practice the specification of the BPLR by banks has turned out to be sticky. Movements in the actual interest rate charged take place less transparently through changes in the proportion of loans above or below the announced BPLR. The share of sub-BPLR lending has, in recent times, increased to over 75 per cent, reflecting the overall decline in interest rates until recently. This has undermined the role of the BPLR as a reference rate, complicating the judgment on monetary transmission with regard to lending rates. 
Table 6

\section{Lending rates of scheduled commercial banks in India}

Per cent

\begin{tabular}{c|c|c|c|c|c|c}
\hline \multirow{2}{*}{} & \multicolumn{2}{|c|}{ Public sector banks } & \multicolumn{2}{c|}{ Foreign banks } & \multicolumn{2}{c}{ Private sector banks } \\
\cline { 2 - 7 } & $\begin{array}{c}\text { Demand } \\
\text { loans }\end{array}$ & Term loans & $\begin{array}{c}\text { Demand } \\
\text { loans }\end{array}$ & Term loans & $\begin{array}{c}\text { Demand } \\
\text { loans }\end{array}$ & Term loans \\
\hline 1 & $\mathbf{2}$ & $\mathbf{3}$ & $\mathbf{4}$ & $\mathbf{5}$ & $\mathbf{6}$ & $\mathbf{7}$ \\
\hline Jun-02 & $12.75-14.00$ & $12.75-14.00$ & $13.00-14.75$ & $13.00-15.50$ & $13.75-16.00$ & $14.00-16.00$ \\
Sep-02 & $12.00-14.00$ & $12.25-14.00$ & $13.00-14.75$ & $12.75-14.50$ & $14.00-16.00$ & $13.50-15.00$ \\
Dec-02 & $11.85-14.00$ & $12.25-14.00$ & $12.00-14.75$ & $11.70-13.63$ & $13.50-15.75$ & $13.50-15.00$ \\
Mar-03 & $11.50-14.00$ & $12.00-14.00$ & $10.50-12.75$ & $10.25-13.50$ & $13.50-15.50$ & $13.00-15.00$ \\
Jun-03 & $11.50-14.00$ & $11.50-14.00$ & $10.00-14.00$ & $9.73-13.00$ & $13.00-15.00$ & $12.50-14.75$ \\
Sep-03 & $11.50-13.50$ & $11.00-13.50$ & $9.50-12.75$ & $9.25-13.50$ & $13.00-14.50$ & $12.00-14.50$ \\
Dec-03 & $11.50-13.00$ & $11.00-13.25$ & $7.75-13.65$ & $9.00-13.00$ & $12.50-14.50$ & $11.50-14.50$ \\
Mar-04 & $11.00-12.75$ & $11.00-12.75$ & $7.50-11.00$ & $8.00-11.60$ & $12.00-14.00$ & $11.25-14.00$ \\
Jun-04 & $10.50-12.50$ & $10.75-12.75$ & $6.50-11.50$ & $7.25-10.95$ & $11.50-13.75$ & $11.00-14.00$ \\
Sep-04 & $10.50-12.50$ & $9.50-12.25$ & $6.75-9.00$ & $7.25-11.00$ & $11.25-13.25$ & $9.50-13.00$ \\
Dec-04 & $9.00-12.50$ & $8.38-12.13$ & $7.25-9.00$ & $7.38-10.95$ & $10.00-13.00$ & $9.25-13.00$ \\
Mar-05 & $9.00-12.50$ & $8.38-12.00$ & $7.13-9.00$ & $7.63-9.50$ & $10.00-12.50$ & $9.00-13.00$ \\
Jun-05 & $8.00-12.13$ & $8.00-11.88$ & $7.75-9.00$ & $7.50-9.50$ & $10.00-12.75$ & $9.00-13.00$ \\
Sep-05 & $8.00-11.63$ & $8.00-11.88$ & $7.00-10.25$ & $7.35-9.50$ & $10.00-12.50$ & $9.00-13.00$ \\
Dec-05 & $8.00-11.63$ & $8.00-11.63$ & $7.00-9.50$ & $7.20-9.50$ & $10.00-13.00$ & $9.25-13.00$ \\
Mar-06 & $8.00-11.63$ & $8.00-11.63$ & $8.00-9.75$ & $7.53-9.75$ & $9.50-13.00$ & $9.00-13.18$ \\
Jun-06 & $8.00-11.25$ & $8.00-12.00$ & $7.63-9.75$ & $7.53-9.75$ & $9.75-13.50$ & $9.23-13.75$ \\
Sep-06 & $8.25-11.50$ & $8.50-12.13$ & $8.08-9.57$ & $7.85-9.75$ & $10.00-13.50$ & $9.45-13.50$ \\
Dec-06 & $8.00-11.88$ & $8.50-12.00$ & $8.05-10.00$ & $8.00-9.50$ & $10.00-13.13$ & $9.23-12.63$ \\
\hline
\end{tabular}

Note: Median lending rates in this table are the range within which at least 60 per cent of business is contracted.

Source: Reserve Bank of India, available at http://rbidocs.rbi.org.in/lendingrate/home.html.

In recent times, there has been some tendency to widen the net of administered interest rates to cover bank loans for agriculture. While such a tendency may not be an unlikely outcome given the predominance of publicly-owned financial intermediaries, it needs to be recognized that the current pricing system for bank loans appears less than satisfactory, particularly in respect of agriculture and small scale industries (SSI). Competition has moved the pricing of a significant proportion of loans far out of alignment with the BPLR and in a non-transparent manner. Thus, there is a public perception that banks' risk assessment processes are less than appropriate and that there is underpricing of credit for corporates, while there could be overpricing of lending to agriculture and SSI. Therefore, the current practices on pricing of credit need to be revamped by banks through well structured, segment-wise analysis of costs at various stages of intermediation in the whole credit cycle. 
The Indian financial system appears to have responded favourably to reforms initiated in the early 1990s with relatively higher efficiency, competitiveness and resilience. This has enabled banks to increase their lending to the commercial sector. Non-food credit extended by scheduled commercial banks recorded an average annual growth of 26.4 per cent between 2002-03 and 2005-06, notably higher than that of 14.5 per cent recorded during the preceding four-year period (1998-99 to 2001-02) as well as the long-run average of 17.8 per cent (1970-2006). Reflecting the growth in bank credit, the ratio of bank credit to GDP has also witnessed a sharp rise. The credit-GDP ratio, after moving in a narrow range of around 30 per cent between mid-1980s and late 1990s, started increasing from 2000-01 onwards to 35 per cent during 2004-05 and further to 40 per cent during 2006-07. The stagnation in credit flow observed during the late 1990s was, in retrospect, partly caused by a reduction in demand on account of an increase in real interest rates, the cyclical down turn and the significant business restructuring that occurred during that period. The sharp expansion in bank credit in the past $4-5$ years also reflects, in part, policy initiatives to improve the flow of credit to sectors like agriculture. While demand for agricultural and industrial credit has remained strong in the current cycle, increasingly, retail credit has emerged as the driver of growth. The strengthening of the banking system has thus worked towards financial widening and deepening. In the process, greater monetization and financial inclusion are extending the net of the formal financial system and, hence, enhancing the scope of monetary transmission.

The increasing reach of formal finance has gradually expanded to cover larger segments of the population. The "demographic dividend" of a larger and younger labour force has meant that banks have been able to expand their loan portfolio rapidly, enabling consumers to satisfy their lifestyle aspirations at a relatively young age with an optimal combination of equity and debt to finance consumption and asset creation. In the process, interest has become a much more potent tool of monetary policy, affecting consumption and investment decisions of the population much more rapidly than was the case earlier. This is evident in the share of retail credit in total bank credit, increasing from around 6 per cent in March 1990 to over 22 per cent in March 2005. A large part of this increase has taken place in the past 5-6 years. In view of this growing share of household credit, it is likely that household consumption decisions, in the coming years, may be more strongly influenced by monetary policy decisions, with implications for the monetary transmission mechanism. Consequently, the monetary authority may need to contend increasingly with public opinion on monetary management, much more than hitherto, given the rising share of personal/household loans. In the context of large scale public ownership of banks, such pressures of public opinion would also manifest themselves into political pressures.

In brief, there is increasing evidence that the bank credit and lending rate channels of monetary transmission are gaining in strength with the widening and deepening of the financial system and the progress towards greater price discovery. A number of constraints continue, however, to interfere with monetary transmission. First, the stipulation of priority sector lending of 40 per cent of net bank credit affects flexibility in sectoral credit allocation, even though there is no interest rate stipulation for the priority sector. Second, allocational flexibility is further constrained under the extant prescription of an SLR of 25 per cent of net demand and time liabilities (NDTL), although the relevant Act has now been amended to give the Reserve Bank flexibility to reduce this statutory liquidity ratio. Third, the system of BPLR for credit pricing has proved to be relatively sticky downward, and more so for specific sectors like agriculture and small scale industries (SSI). As the BPLR has ceased to be a reference rate, assessment of the efficacy of monetary transmission has become difficult. Fourth, the Government of India continues to own around 70 per cent of banks' assets. While the Government, as a legitimate owner, is entitled to issue direction to public sector banks, such exercise by the Government introduces elements of uncertainty and market imperfections, impacting monetary transmission. 


\title{
III.4 Debt market channel
}

While government debt management was one of the motivating factors for the setting up of central banks in many countries, currently the function, with its focus on lowering the cost of public debt, is often looked upon as constraining monetary management, particularly when compulsions of monetary policy amidst inflation expectations may necessitate a tighter monetary policy stance. Therefore, it is now widely believed that the two functions monetary policy and public debt management - need to be conducted in a manner that ensures transparency and independence in monetary operations. The fuller development of financial markets, reasonable control over the fiscal deficit and necessary legislative changes are regarded as pre-conditions for separation of debt management from monetary management. The Reserve Bank currently performs the twin function of public debt and monetary management.

"The logical question that follows is whether the experience of fiscal dominance over monetary policy would have been different if there had been separation of debt management from monetary management in India? Or, were we served better with both the functions residing in the Reserve Bank? What has really happened is that there was a significant change in thinking regarding overall economic policy during the early 1990s, arguing for a reduced direct role of the Government in the economy. A conscious view emerged in favour of fiscal stabilisation and reduction of fiscal deficits aimed at eliminating the dominance of fiscal policy over monetary policy through the prior practice of fiscal deficits being financed by automatic monetization. It is this overall economic policy transformation that has provided greater autonomy to monetary policy making in the 1990s.

\begin{abstract}
"The Indian economy has made considerable progress in developing its financial markets, especially the government securities market since 1991. Furthermore, fiscal dominance in monetary policy formulation has significantly reduced in recent years. With the onset of a fiscal consolidation process, withdrawal of the $\mathrm{RBI}$ from the primary market of Government securities and expected legislative changes permitting a reduction in the statutory minimum Statutory Liquidity Ratio, fiscal dominance would be further diluted. All of these changes took place despite the continuation of debt management by the Reserve Bank. Thus, one can argue that effective separation of monetary policy from debt management is more a consequence of overall economic policy thinking rather than adherence to a particular view on institutional arrangements" (Mohan, 2006b).
\end{abstract}

The Fiscal Responsibility and Budget Management (FRBM) Act, 2003 has set the stage for a front-loaded fiscal correction path for the Central Government. Similar enactments have also taken place in a number of States. As already mentioned, the FRBM Act, 2003 has prohibited the Reserve Bank from participating in primary issuance of government securities with effect from April 1, 2006, except under exceptional circumstances. In preparation, the institutional structures within the Reserve Bank have been modified to strengthen monetary operations with a view to moving towards functional separation between debt management and monetary operations. Accordingly, a new Financial Markets Department (FMD) has been constituted to undertake (i) monetary operations, (ii) regulation and development of money market instruments and (iii) monitoring of money, government securities and foreign exchange markets. The enactment of the FRBM Act has arguably strengthened monetary transmission through the debt market. It has also mitigated the possibility of conflict in monetary policy in order to contain the cost of Government borrowing.

The auction-based issue of government debt according to a pre-announced calendar has enabled price discovery and liquidity in the market. A Negotiated Dealing System was introduced in February 2002 to facilitate electronic bidding, secondary market trading and settlement and to disseminate information on trades on a real-time basis. In the context of 
the Reserve Bank's absence from primary auctions, a "when, as and if issued" market in Government securities has been allowed recently.

Vibrant secondary market trading has helped to develop a yield curve and the term structure of interest rates. This has facilitated pricing of debt instruments in various market segments and, thereby, monetary transmission across maturity and financial instruments. While market yields, at times, turn out to be puzzling, particularly in the wake of global policy signaling as as well as in times of re-pricing of risks, the reverse repo rate set out by the Reserve Bank remains the overnight floor for the market. The falling interest rate scenario witnessed up to 2003-04 and the comfortable liquidity position in the system had helped to bring down yields and the yield curve turned relatively flat. Long-term yields, however, continue to be impervious across the globe to subsequent reversal of the interest rate cycle, giving rise to a "conundrum" a la Greenspan (2005). In the Indian context, the transmission from shorter to longer end of the yield curve has been vacillating, linked, inter alia, to changes in monetary policy rates, inflation rates, international interest rates and, on other occasions, the SLR stipulation. With the increasing openness of the domestic economy, it appears that international economic developments are set to exert a greater influence on the domestic yield curve than before. Thus, even in the absence of fuller capital account convertibility, monetary transmission may need to contend with impulses that arise from international developments. Furthermore, the process of fiscal consolidation currently underway could potentially lead to a situation of excess demand for government securities in relation to their supply, which would, in turn, impact the shape of the yield curve and, thereby, impede monetary transmission. The stipulation for SLR could also undergo a change guided by prudential considerations, affecting, in the process, the demand for government securities and, thereby, the yield curve as banks remain invested with government securities for the purpose of SLR. Such developments, however, may not be in consonance with the monetary policy stance and hence, could get in the way of intended monetary transmission.

While the government securities market is fairly well developed now, the corporate debt market remains to be developed for facilitating monetary signaling across various market segments. In the absence of a well developed corporate debt market, the demand for debt instruments has largely concentrated on government securities, with the attendant implications for the yield curve and, in turn, for monetary transmission. The secondary market for corporate debt has suffered from a lack of market making, resulting in poor liquidity. Corporates continue to prefer private placements to public issues for raising resources in view of ease of procedures and lower costs. There is a need for development of mortgage-backed securities, credit default swaps, bond insurance institutions for credit enhancement, abridgment of disclosure requirements for listed companies, rating requirements for unlisted companies, real time reporting of primary and secondary trading, retail access to bond market by non-profit institutions and small corporates and access to RTGS. A concerted effort is now being made to set up the institutional and technological structure that would enable the corporate debt market to operate. Furthermore, the on-going reforms in the area of social security coupled with the emergence of pension and provident funds are expected to increase the demand for long-term debt instruments. In the process, the investor base for government securities would be broadened, extending the monetary transmission across new players and participants.

\section{III.5 Exchange rate channel}

The foreign exchange market in India has acquired increasing depth with the transition to a market-determined exchange rate system in March 1993 and the subsequent gradual but significant relaxation of restrictions on various external transactions. Payment restrictions on all current account transactions were removed with the acceptance of the obligations of Article VIII of the IMF's Articles of Agreement in August 1994. While the rupee remains virtually convertible on the capital account for foreign nationals and non-resident Indians (NRIs), similar moves are on course for the domestic residents. Significant relaxations have 
been allowed for capital outflows in the form of direct and portfolio investment, non-resident deposits, repatriation of assets and funds held abroad. Indian residents can now open foreign currency accounts with banks in India.

The major initiatives taken to widen and deepen the Indian forex market and to link it with the global financial system have been: (i) freedom for banks to fix net overnight position limits and gap limits, initiate trading positions in the overseas markets, and use derivative products for asset-liability management; (ii) permission for authorised dealers (ADs) in foreign exchange to borrow abroad up to limits related to their capital base as a prudential measure; and (iii) freedom for corporates to hedge anticipated exposures, cancel and rebook forward contracts. The CCIL has commenced settlement of forex operations for inter-bank US Dollar/Indian rupee spot and forward trades from November 2002 and inter-bank US dollar/Indian rupee cash and tom trades from February 2004.

The annual turnover in the foreign exchange market has increased more than threefold from US \$ 1434 billion in 2000-01 to US \$ 4413 billion in 2005-06 (Table 7). Inter-bank transactions continue to account for the bulk of the transactions in the forex market, albeit with a declining share over the years. The forward market segment (swaps plus forward) is also growing at a faster pace. Reflecting the build-up of forex reserves, the strong capital flows and the confidence in the Indian economy, forward premia have come down sharply from the peak reached in 1995-96. Under the market-determined exchange rate regime, the Indian rupee has exhibited two-way movements and the foreign exchange market has displayed stable conditions, as reflected in the annual coefficient of variation of 0.9-2.3 per cent during 2000-01 to 2005-06. The exchange rate policy of the Reserve Bank in recent years has been guided by the broad principles of careful monitoring and management of exchange rates with flexibility, without a fixed target or a pre-announced target or a band, coupled with the ability to intervene, if and when necessary.

Table 7

Foreign exchange market: Activity indicators

\begin{tabular}{c|c|c|c|c|c|c}
\hline Year & $\begin{array}{c}\text { Foreign } \\
\text { exchange } \\
\text { market- } \\
\text { annual } \\
\text { turnover } \\
\text { (US \$ billion) }\end{array}$ & $\begin{array}{c}\text { Gross } \\
\text { volume of } \\
\text { BoP } \\
\text { transactions } \\
\text { (US \$ } \\
\text { billion) }\end{array}$ & $\begin{array}{c}\text { RBI's } \\
\text { foreign } \\
\text { currency } \\
\text { assets } \\
\text { (US \$ } \\
\text { billion) }\end{array}$ & $\begin{array}{c}\text { CV of } \\
\text { exchange } \\
\text { rate of } \\
\text { rupee } \\
\text { (per cent) }\end{array}$ & $\begin{array}{c}\text { Col 2 over } \\
\text { Col 3 }\end{array}$ & $\begin{array}{c}\text { Col 2 over } \\
\text { Col 4 }\end{array}$ \\
\hline $\mathbf{1}$ & $\mathbf{2}$ & $\mathbf{3}$ & $\mathbf{4}$ & $\mathbf{5}$ & $\mathbf{6}$ & $\mathbf{7}$ \\
\hline $2000-01$ & 1434 & 258 & 40 & 2.3 & 5.6 & 36 \\
$2001-02$ & 1487 & 237 & 51 & 1.4 & 6.3 & 29 \\
$2002-03$ & 1585 & 267 & 72 & 0.9 & 5.9 & 22 \\
$2003-04$ & 2141 & 362 & 107 & 1.6 & 5.9 & 20 \\
$2004-05$ & 2892 & 481 & 136 & 2.3 & 6.0 & 21 \\
$2005-06$ & 4413 & 657 & 145 & 1.5 & 6.7 & 30 \\
\hline
\end{tabular}

${ }^{1}$ At end-March; CV: Coefficient of variation; BoP: Balance of payments.

Source: Reserve Bank of India. 
Exchange rate flexibility, coupled with the gradual removal of capital controls, has widened the scope for monetary maneuverability, enabling transmission through exchange rates. In the event of interest rate arbitrage triggered by monetary policy action, foreign exchange inflows can tend to pick up until the interest rate parity is restored by exchange rate adjustments. An appreciating exchange rate, in turn, would have a dampening effect on aggregate demand, containing inflationary pressures. However, if large segments of economic agents lack adequate resilience to withstand volatility in currency and money markets, the option of exchange rate adjustments may not be available, partially or fully. Therefore, the central bank may need to carry out foreign exchange operations for stabilizing the market. In the process, the injection of liquidity into the system by the central bank would go against its policy stance and weaken monetary transmission. Thus, monetary management becomes complicated, and the monetary authority may need to undertake offsetting sterilization transactions in defence of monetary stability and intended transmission. In the Indian context, faced with similar circumstances, sterilization operations have been carried out from 2004 through issuance of government securities under the Market Stabilisation Scheme (MSS).

Available evidence suggests that exchange rate depreciation has the expected effect of raising domestic prices and the coefficient of exchange rate pass-through to domestic inflation ranges between 8-17 basis points (depending upon the measure of inflation), ie, a 10 per cent depreciation of the Indian rupee (vis-a-vis the US dollar) would, other things remaining unchanged, increase consumer inflation by less than 1 percentage point and the GDP deflator by 1.7 percentage points. Rolling regressions suggest some decline in the exchange rate pass-through coefficient in recent years (RBI, 2004b). The coefficient on the exchange rate exhibits a declining trend, although the estimates turn out to be somewhat imprecise. This suggests a possible decline in exchange rate pass-through to domestic inflation. The decline in pass-through during the 1990s is consistent with the cross-country evidence. In India, inflation rates have declined significantly since the second half of the 1990s and this could be one explanation for the lower pass-through. Another key factor that could have lowered the pass-through is the phased decline in tariffs as well as non-tariff barriers such as quotas. Average import duties are now less than one-third of what they were a decade ago. This steep reduction in tariffs could have easily allowed domestic producers to absorb some part of the exchange rate depreciation without any effect on their profitability.

Another factor that could reduce the pass-through is related to globalization and "Walmartization". The increased intensity of globalization and the commodification of many goods have perhaps reduced the pricing power of producers, particularly of low technology goods in developing countries, whereas the pricing power of large retailers like Walmart has risen. The decline in pass-through across a number of countries, as suggested by various studies, has implications for the efficacy of the exchange rate as an adjustment tool. The lower pass-through suggests that, in the new globalised economy, exchange rate adjustments as a means of correction of imbalances may have become less potent; if so, then the swing in exchange rates to correct emerging imbalances will have to be much larger than before, eventually bringing greater instability in their wake (Mohan, 2004).

\section{III.6 Communication and expectations channel}

In a market-oriented economy, well-informed market participants are expected to enable an improved functioning of the markets, and it is held that a central bank is in the best position to provide such useful information to the market participants. Whether providing information would result in shaping and managing expectations, and if so, whether it is desirable, remain unsettled issues. There are several dilemmas faced by central banks while designing an appropriate communications policy. First, what should be communicated and to what degree of disaggregation? The second set relates to: at what stage of evolution of internal thinking and debate should there be dissemination? The third set relates to the timing of communication with reference to its market impact. The fourth relates to the quality of 
information and the possible ways in which it could be perceived. Thus, alleged incoherence or an element of ambiguity at times on the part of central bankers in explaining policies is as much a reflection of the complexity of the issues as it is of the differing perceptions of a variety of audiences to which the communication is addressed. It is essential to appreciate that communication policy is not merely about explaining or getting feedback on policy, but may include elements of influencing the policy direction itself. A central bank does this through several channels, including research publications and speeches (Reddy, 2001; 2006). It is recognised that credible communication and creative engagement with the market and economic agents have emerged as the critical channel of monetary transmission as against the traditional channels. For example, the US Federal Reserve, since 1994, appears to have been providing forward guidance, while the European Central Bank appears to be in the mould of keeping the markets informed rather than guiding it.

With the widening and deepening of inter-linkages between various segments of financial markets, the Reserve Bank has adopted a consultative process for policy making in order to ensure timely and effective implementation of the measures. The Bank has taken a middle path of sharing its analysis in addition to providing information, but in no way guiding the market participants. However, in doing so, the RBI has the benefit of the process of two-way communication, of information as well as perceptions, between the market participants and the RBI. In the process, the Bank's signaling/announcements are increasingly seen to have an influence on expectations formation in the market.

The more complex the mandate for the central bank, the greater the need for communication (Mohan, 2005). The Reserve Bank of India clearly has complex objectives. Apart from pursuing monetary policy, financial stability is one of the overriding concerns of the RBI. Within the objective of monetary policy, both control of inflation and providing adequate credit to the productive sectors of the economy so as to foster growth are equally important. This apart, the Reserve Bank acts as a banking regulator, public debt manager, government debt market regulator and currency issuer. Faced with such multiple tasks and complex mandate, there is an utmost necessity of clearer communication on the part of the Reserve Bank.

In general, for a central bank, there is a need for three kinds of communication: (a) policy measures, (b) reasons behind such policy measures and (c) analysis of the economy. The Reserve Bank is engaged with all three kinds of communication. In fact, by international standards the Reserve Bank has a fairly extensive and transparent communication system. Policy statements (quarterly since April 2005 onwards and bi-annual prior to this period) have traditionally communicated the Reserve Bank's stance on monetary policy in the immediate future of six months to one year. The practice of attaching a review of macroeconomic developments to the quarterly reviews gives an expansive view of how the central bank sees the economy. In the bi-annual policy meetings with leading bankers, the Governor explains the rationale behind the measures at length. These policy meetings are not one-way traffic. Each banker present in the meeting interacts with the Governor to express his or her reaction to the policy announcement. After the policy announcement is over, the Governor addresses a press conference in the afternoon. The Deputy Governor in charge of monetary policy normally gives live interviews to all the major television channels on the same day. The Governor also gives interviews to print and electronic media over the next few days after the monetary policy announcement.

Communication of policy also takes place through speeches of the Governor and Deputy Governors, and various periodic reports. A significant step towards transparency of monetary policy implementation is formation of various Technical Advisory Committees (TACs) in the Reserve Bank with representatives from market participants, other regulators and experts. In line with the international best practices and with a view to further strengthening the consultative process in monetary policy, the Reserve Bank, in July 2005, set up a Technical Advisory Committee on Monetary Policy (TACMP) with external experts in the areas of monetary economics, central banking, financial markets and public finance. The Committee meets at least once a quarter, reviews macroeconomic and monetary developments and 
advises the Reserve Bank on the stance of monetary policy. The Committee has contributed to enriching the inputs and processes of monetary policy setting in India. Recognizing the importance of expectations in the conduct and formulation of monetary policy, the Reserve Bank has recently initiated surveys of business and inflation expectations.

Finally, in the context of growing openness of the Indian economy and increasing integration with the rest of the world, global economic and financial developments - such as monetary policy decisions of the US Fed and other major economies and trends in international crude oil prices - are also shaping expectations. The Reserve Bank also takes such factors and expectations into account. ${ }^{3}$

The process of monetary policy formulation in India is now relatively transparent, consultative and participative with external orientation, and this has contributed to stabilizing expectations of market participants. Illustratively, an important element in coping with liquidity management has been the smoothing behaviour of the Reserve Bank and its communication strategy. In August 2004, the headline inflation rate shot up to 8.7 per cent, partly on account of rising global oil prices and partly due to a resurgence in manufacturing inflation. The turning of the interest rate cycle looked imminent. The issue was addressed through burden sharing by appropriate monetary and fiscal coordination and by preparing markets for a possible interest rate reversal. In measured and calibrated steps the monetary policy stance was changed and measures such as those on CRR and reverse repos were taken in a phased manner. Also, banks were allowed to transfer HFT (Held for Trading) and AFS (Available for Sale) securities to the HTM (Held to Maturity) category, thereby affording them some cushion against the possible interest rate shock. Markets were prepared with a careful communication on the stance of the monetary policy stating that the central bank would strive for provision of appropriate liquidity while placing equal emphasis on price stability. Monetary management thus succeeded in building credibility and keeping inflation expectations low.

In brief, there has been a noteworthy improvement in the operational efficiency of monetary policy from the early 1990s. Financial sector reforms and the contemporaneous development of the money market, Government securities market and the foreign exchange market have strengthened monetary transmission by enabling more efficient price discovery, and improving allocative efficiency even as the RBI has undertaken developmental efforts to ensure the stability and smooth functioning of financial markets. The approach has been one of simultaneous movement on several fronts, graduated and calibrated, with an emphasis on institutional and infrastructural development and improvements in market microstructure. The pace of the reform was contingent upon putting in place appropriate systems and procedures, technologies and market practices. There has been close co-ordination between the Government and the RBI, as well as between different regulators, which helped in the orderly and smooth development of the financial markets in India. Markets have now grown in size, depth and activity, paving the way for flexible use of indirect instruments. The Reserve Bank has also engaged in refining the operating procedures and instruments as well as risk management systems, income recognition and provisioning norms, disclosure norms, accounting standards and insolvency in line with international best practices with a view to fostering the seamless integration of Indian financial markets with global markets.

3 Illustratively, the Reserve Bank in its Annual Policy Statement for 2006-07 (April 2006) stressed that: "Domestic macroeconomic and financial conditions support prospects of sustained growth momentum with stability in India. It is important to recognise, however, that there are risks to both growth and stability from domestic as well as global factors. At the current juncture, the balance of risks is tilted towards the global factors. The adverse consequences of further escalation of international crude prices and/or of disruptive unwinding of global imbalances are likely to be pervasive across economies, including India. Moreover, in a situation of generalised tightening of monetary policy, India cannot afford to stay out of step. It is necessary, therefore, to keep in view the dominance of domestic factors as in the past but to assign more weight to global factors than before while formulating the policy stance" (RBI, 2006). 


\section{How well do monetary transmission channels work?}

Turning to an assessment of monetary policy transmission, it would be reasonable to assert that monetary policy has been largely successful in meeting its key objectives in the postreforms period. There has been a fall in inflation worldwide since the early 1990s, and in India since the late 1990s. Inflation has averaged close to 5 per cent per annum in the decade gone by, notably lower than the 8 per cent of the previous four decades (Chart 6). Structural reforms since the early 1990s coupled with improved monetary-fiscal interface and reforms in the Government securities market enabled better monetary management from the second half of the 1990s onwards. More importantly, the regime of low and stable inflation has, in turn, stabilised inflation expectations, and inflation tolerance in the economy has come down. It is encouraging to note that despite record high international crude oil prices, inflation remains low and inflation expectations also remain stable (Table 8). Since inflation expectations are a key determinant of the actual inflation outcome, and given the lags in monetary transmission, the Reserve Bank has been taking pre-emptive measures to keep inflation expectations stable. As discussed earlier, a number of instruments, both existing as well as new, were employed to modulate liquidity conditions to achieve the desired objectives. A number of other factors such as increased competition, productivity gains and strong corporate balance sheets have also contributed to this low and stable inflation environment, but it appears that calibrated monetary measures had a substantial role to play as well.

Chart 6

\section{GDP growth and WPI and CPI inflation}

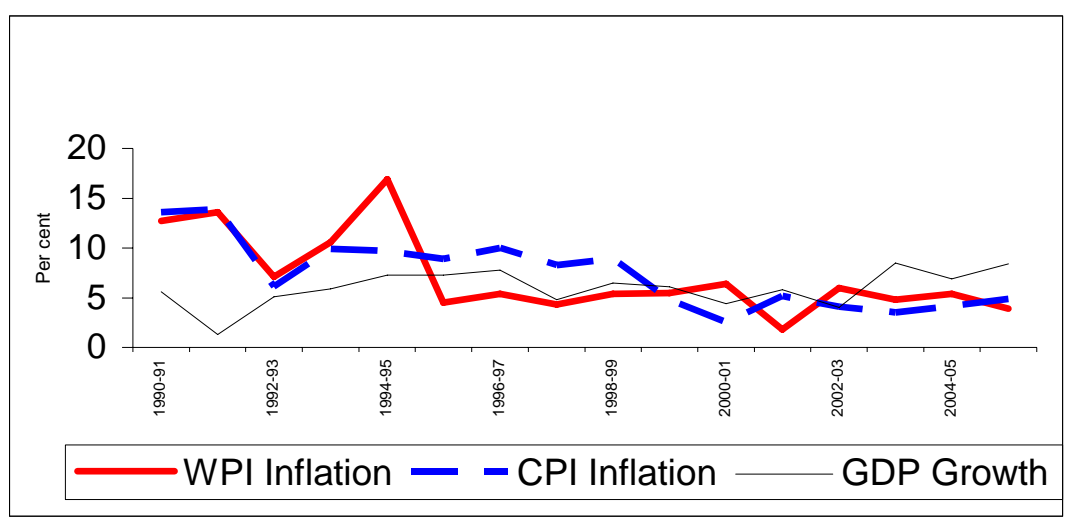

In the context of the recent firming up of core as against headline inflation particularly in industrial countries, primarily on account of higher non-oil commodity prices, issues of proper measurement of inflation and inflationary pressures have attracted renewed debate. In particular, the debate involves the relevance of core inflation as a guide for the conduct of monetary policy vis-à-vis the use of headline inflation. In India, core inflation is not considered as relevant for several reasons, but mainly because the two major sources of supply shock, food and fuel, account for a large share of the index. Further, in the absence of a harmonized consumer price index for India, the use of core inflation based on wholesale prices may not be very meaningful. While the permanent component is judgmental, broad magnitudes could be perceived and articulated. Such an explanatory approach to headline and underlying inflation pressure in monetary policy has added credibility to the policy and influenced and guided the inflation expectations in India. 
Table 8

Wholesale price inflation (WPI) and consumer price inflation (CPI)

Year-on-year

Per cent

\begin{tabular}{l|c|c|c|c|c|c|c|c}
\hline $\begin{array}{c}\text { Inflation } \\
\text { Measure }\end{array}$ & $\begin{array}{c}\text { March } \\
\mathbf{2 0 0 0}\end{array}$ & $\begin{array}{c}\text { March } \\
\mathbf{2 0 0 1}\end{array}$ & $\begin{array}{c}\text { March } \\
\mathbf{2 0 0 2}\end{array}$ & $\begin{array}{c}\text { March } \\
\mathbf{2 0 0 3}\end{array}$ & $\begin{array}{c}\text { March } \\
\mathbf{2 0 0 4}\end{array}$ & $\begin{array}{c}\text { March } \\
\mathbf{2 0 0 5}\end{array}$ & $\begin{array}{c}\text { March } \\
\mathbf{2 0 0 6}\end{array}$ & $\begin{array}{c}\text { February } \\
\mathbf{2 0 0 7}\end{array}$ \\
\hline \multicolumn{1}{c}{$\mathbf{1}$} & $\mathbf{2}$ & $\mathbf{3}$ & $\mathbf{4}$ & $\mathbf{5}$ & $\mathbf{6}$ & $\mathbf{7}$ & $\mathbf{8}$ & $\mathbf{9}$ \\
\hline WPI Inflation & & & & & & & & \\
(end-Month) & 6.5 & 5.5 & 1.6 & 6.5 & 4.6 & 5.1 & 4.1 & $6.6^{1}$ \\
CPI-IW & 4.8 & 2.5 & 5.2 & 4.1 & 3.5 & 4.2 & 4.9 & $6.9^{2}$ \\
CPI-UNME & 5.0 & 5.6 & 4.8 & 3.8 & 3.4 & 4.0 & 5.0 & $6.9^{2}$ \\
CPI-AL & 3.4 & -2.0 & 3.0 & 4.9 & 2.5 & 2.4 & 5.3 & $9.5^{3}$ \\
CPI-RL & $\ldots$ & -1.6 & 3.0 & 4.8 & 2.5 & 2.4 & 5.3 & $8.9^{3}$ \\
\hline
\end{tabular}

...: Not available; IW: Industrial workers; UNME: Urban non-manual employees; AL: Agricultural labourers; $\mathrm{RL}$ : Rural labourers.

1 As on February 10, 2007; ${ }^{2}$ As in December 2006; ${ }^{3}$ As in January 2007.

Source: Annual Report and Handbook of Statistics of Indian Economy, various issues, Reserve Bank of India.

Table 9

Monetary policy and corporate performance: interest rate-related indicators

\begin{tabular}{l|c|c|c}
\hline Year & $\begin{array}{c}\text { Growth rate in interest } \\
\text { expenses (\%) }\end{array}$ & $\begin{array}{c}\text { Debt service to total } \\
\text { uses of funds ratio }\end{array}$ & Interest coverage ratio $^{2}$ \\
\hline $1990-91$ & 16.2 & 22.4 & 1.9 \\
$1991-92$ & 28.7 & 28.3 & 1.9 \\
$1992-93$ & 21.6 & 24.4 & 1.6 \\
$1993-94$ & 3.1 & 20.9 & 2.0 \\
$1994-95$ & 8.1 & 27.2 & 2.4 \\
$1995-96$ & 25.0 & 21.5 & 2.7 \\
$1996-97$ & 25.7 & 18.7 & 2.1 \\
$1997-98$ & 12.5 & 8.1 & 1.9 \\
$1998-99$ & 11.1 & 17.6 & 1.6 \\
$1999-00$ & 6.7 & 17.6 & 1.7 \\
$2000-01$ & 7.1 & 14.0 & 1.7 \\
$2001-02$ & -2.7 & 19.4 & 1.7 \\
$2002-03$ & -11.2 & 8.9 & 2.3 \\
$2003-04$ & -11.9 & 12.7 & 3.3 \\
$2004-05$ & -5.8 & 21.8 & 4.6 \\
\hline 1 & Represents the ratio of loans and advances plus interest accrued on loan to total uses of funds. \\
2 Represents the ratio of gross profit (ie, earning before interest and taxes) to interest expenses. \\
Source: The data is based on selected non-government, non-financial, public limited companies, collected by \\
RBI.
\end{tabular}


How did monetary policy support the growth momentum in the economy? As inflation, along with inflation expectations, fell during the earlier period of this decade, policy interest rates were also brought down. Consequently, both nominal and real interest rates fell. The growth rate in interest expenses of the corporates declined consistently since 1995-96, from 25.0 per cent to a negative of 5.8 per cent in 2004-05 (Table 9). Such decline in interest costs has significant implications for the improvement in bottom lines of the corporates. Various indicators pertaining to interest costs, which can throw light on the impact of interest costs on corporate sector profits, have turned positive in recent years.

\section{What is needed to improve monetary transmission?}

While the changes in policy rates are quickly mirrored in the money market rates as well as in Government bond yields, lending and deposit rates of banks exhibit a degree of downward inflexibility. In this context, administered interest rates fixed by the Government on a number of small saving schemes and provident funds are of special relevance as they generally offer a rate higher than corresponding instruments available in the market as well as tax incentives (RBI, 2001; RBI, 2004a). As banks have to compete for funds with small saving schemes, the rates offered on long-term deposits mobilized by banks set the floor for lending rates at a level higher than would have obtained under competitive market conditions (Chart 7). In fact, this was observed to be a factor contributing to downward stickiness of lending rates, with implications for the effectiveness of monetary policy (Table 10).

\section{Chart 7}

Bank lending rate, deposit rate and small saving rate

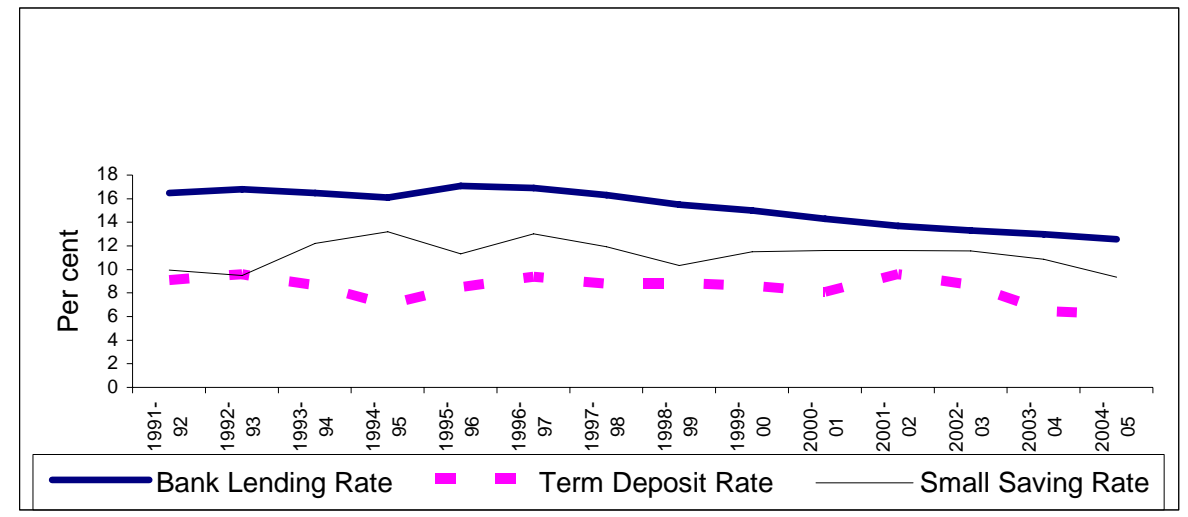

These small savings schemes administered by the Government through the wide reach of post offices, and some through commercial banks, give small savers access to tax savings instruments that are seen as safe and stable. Benchmarking these administered interest rates to market-determined rates has been proposed from time to time. Whereas some rationalization in such schemes has taken place, further progress in this direction will depend on the provision of better social security and pension systems, and perhaps easier access to marketable sovereign instruments (Mohan, 2006c). 
Table 10

Small savings and bank deposits

Amount in Rupees billion

\begin{tabular}{c|c|c|c|c|c}
\hline & $\begin{array}{c}\text { Average } \\
\text { interest rate } \\
\text { on small } \\
\text { savings (\%) }\end{array}$ & $\begin{array}{c}\text { Small savings } \\
\text { outstanding }\end{array}$ & $\begin{array}{c}\text { Average } \\
\text { interest rate } \\
\text { on banks' } \\
\text { term deposits } \\
\text { (\%) }\end{array}$ & $\begin{array}{c}\text { Bank term } \\
\text { deposits } \\
\text { outstanding }\end{array}$ & $\begin{array}{c}\text { Small savings } \\
\text { as \% of Bank } \\
\text { deposits }\end{array}$ \\
\hline $\mathbf{1}$ & $\mathbf{2}$ & $\mathbf{3}$ & $\mathbf{4}$ & $\mathbf{5}$ & $\mathbf{6}$ \\
\hline $1991-92$ & 9.95 & 586 & 9.1 & 2,308 & 25.4 \\
$1992-93$ & 9.48 & 609 & 9.6 & 2,686 & 22.7 \\
$1993-94$ & 12.21 & 677 & 8.7 & 3,151 & 21.5 \\
$1994-95$ & 13.20 & 833 & 7.0 & 3,869 & 21.5 \\
$1995-96$ & 11.33 & 937 & 8.5 & 4,338 & 21.6 \\
$1996-97$ & 13.03 & 1,061 & 9.4 & 5,056 & 21.0 \\
$1997-98$ & 11.92 & 1,268 & 8.8 & 5,985 & 21.2 \\
$1998-99$ & 10.34 & 1,553 & 8.9 & 7,140 & 21.7 \\
$1999-00$ & 11.50 & 1,875 & 8.6 & 8,133 & 23.1 \\
$2000-01$ & 11.60 & 2,251 & 8.1 & 8,201 & 27.4 \\
$2001-02$ & 11.61 & 2,629 & 9.6 & 9,503 & 27.7 \\
$2002-03$ & 11.56 & 3,138 & 8.7 & 10,809 & 29.0 \\
$2003-04$ & 10.88 & 3,758 & 6.5 & 12,794 & 29.4 \\
$2004-05$ & 9.37 & 4,577 & 6.2 & 14,487 & 31.6 \\
$2005-06$ & 8.91 & 5,246 & & 17,444 & 30.1 \\
\hline
\end{tabular}

Source: Annual Report and Handbook of Statistics on the Indian Economy, various issues, Reserve Bank of India.

In consonance with the objective of enhancing the efficiency and productivity of banks through greater competition - from new private sector banks and the entry and expansion of several foreign banks - there has been a consistent decline in the share of public sector banks in total assets of commercial banks. Notwithstanding such transformation, public sector banks still account for over 70 per cent of assets and income of commercial banks. While the public sector banks have responded well to the new challenges of competition, this very public sector character does influence their operational flexibility and decision making and, hence, interferes, on occasions, with the transmission of monetary policy impulses. Similar influence on monetary transmission is exerted by the priority sector directives in terms of allocation of 40 per cent of credit for specified sectors. The impact is, however, very limited now with the deregulation of lending rates and the rationalization of the sectors for priority credit allocation. 


\section{Summing up}

The brief survey of monetary policy transmission in India suggests that monetary policy impulses impact on output and prices through interest rates and exchange rate movements in addition to the traditional monetary and credit aggregates. It is necessary, however, to take note of a few caveats. First, the transmission lags are surrounded by a great deal of uncertainty. In view of the ongoing structural changes in the real sector as well as financial innovations, the precise lags may differ in each business cycle. Second, the period was also marked by heightened volatility in the international economy, including developments such as the series of financial crises beginning with the Asian crisis. Third, the period under study has been marked by sharp reductions in customs duties and increasing trade openness, which could have impacted the transmission process. The 1990s were also witness to global disinflation. Overall, the period has been one of substantial ongoing changes in various spheres of the Indian economy as well as in its external environment. Fourth, the period of study has been characterized by significant shifts in the monetary policy operating framework from a monetary-targeting framework to a multiple indicator approach. Fifth, the size of interest rate pass-through has increased in recent years, with implications for transmission. Finally, empirical investigation is constrained by the use of industrial production as a measure of output in the absence of a reasonably long time series on quarterly GDP of the economy. In view of the significant structural shifts towards the services sector and the interlinkages between agriculture, industry and services, the results of these empirical exercises should be considered tentative and need to be ratified with a comprehensive measure of output, as well as by considering alternative techniques.

On the whole, the Indian experience highlights the need for emerging market economies to allow greater flexibility in exchange rates but the authorities can also benefit from the capacity to intervene in foreign exchange markets in view of the volatility observed in international capital flows. Therefore, there is a need to maintain an adequate level of foreign exchange reserves and this in turn both enables and constrains the conduct of monetary policy. A key lesson is that flexibility and pragmatism are required in the management of the exchange rate and monetary policy in developing countries rather than adherence to strict theoretical rules. 


\section{Annex I: \\ Reforms in the monetary policy framework}

\section{Objectives}

- $\quad$ Twin objectives of "maintaining price stability" and "ensuring availability of adequate credit to productive sectors of the economy to support growth" continue to govern the stance of monetary policy, although the relative emphasis on these objectives has varied depending on the importance of maintaining an appropriate balance.

- Reflecting the increasing development of the financial market and greater liberalization, the use of broad money as an intermediate target has been deemphasised and a multiple indicator approach has been adopted.

- $\quad$ Emphasis has been put on development of multiple instruments to transmit liquidity and interest rate signals in the short-term in a flexible and bi-directional manner.

- Increase of the interlinkage between various segments of the financial market including money, government security and forex markets.

\section{Instruments}

- Move from direct instruments (such as administered interest rates, reserve requirements, selective credit control) to indirect instruments (such as open market operations, purchase and repurchase of government securities) for the conduct of monetary policy.

- Introduction of Liquidity Adjustment Facility (LAF), which operates through repo and reverse repo auctions, effectively providing a corridor for short-term interest rates. LAF has emerged both as the tool for liquidity management and as a signalling devise for interest rates in the overnight market.

- Use of open market operations to deal with overall market liquidity situation, especially those emanating from capital flows.

- Introduction of Market Stabilisation Scheme (MSS) as an additional instrument to deal with enduring capital inflows without affecting the short-term liquidity management role of LAF.

\section{Developmental measures}

- Discontinuation of automatic monetization through an agreement between the Government and the Reserve Bank. Rationalization of Treasury Bill market. Introduction of delivery versus payment system and deepening of inter-bank repo market.

- Introduction of Primary Dealers in the government securities market to play the role of market maker.

- $\quad$ Amendment of Securities Contracts Regulation Act (SCRA), to create the regulatory framework. 
- $\quad$ Deepening of the government securities market by making the interest rates on such securities market-related. Introduction of auctions of government securities. Development of a risk-free credible yield curve in the government securities market as a benchmark for related markets.

- Development of a pure inter-bank call money market. Non-bank participants to participate in other money market instruments.

- Introduction of automated screen-based trading in government securities through Negotiated Dealing System (NDS). Setting up of risk-free payments and system in government securities through Clearing Corporation of India Limited (CCIL). Phased introduction of a Real Time Gross Settlement (RTGS) System.

- $\quad$ Deepening of the forex market and increased autonomy of Authorised Dealers.

\section{Institutional measures}

- $\quad$ Setting up of Technical Advisory Committee on Monetary Policy with outside experts to review macroeconomic and monetary developments and advise the Reserve Bank on the stance of monetary policy.

- $\quad$ Creation of a separate Financial Market Department within the RBI. 


\section{Annex II: Money market instruments for liquidity management}

The Reserve Bank has been making efforts to develop a repo market outside the LAF for bank and non-bank participants, so as to provide a stable collateralised funding alternative with a view to promoting smooth transformation of the call/notice money market into a pure inter-bank market and for deepening the underlying Government securities market. Thus, the following new instruments have been introduced.

\section{Collateralised borrowing and lending obligation (CBLO)}

- $\quad$ Developed by the Clearing Corporation of India Limited (CCIL) and introduced on January 20,2003 , it is a discounted instrument available in electronic book entry form for the maturity period ranging from one day to ninety days (can be made available up to one year as per RBI guidelines).

- In order to enable the market participants to borrow and lend funds, CCIL provides the Dealing System through the Indian Financial Network (INFINET), a closed user group for the Members of the Negotiated Dealing System (NDS) who maintain a current account with the RBI, and through the Internet for other entities who do not maintain a current account with the RBI.

- $\quad$ Membership (including Associate Membership) of the CBLO segment is extended to banks, financial institutions, insurance companies, mutual funds, primary dealers, NBFCs, non-Government provident funds, corporates, etc.

- $\quad$ Eligible securities are Central Government securities including Treasury Bills.

- $\quad$ Borrowing limits for members are fixed by the CCIL at the beginning of the day taking into account the securities deposited by borrowers in their CSGL account with CCIL. The securities are subjected to the necessary hair-cut after marking them to market.

- $\quad$ The auction market is available only to NDS Members for overnight borrowing and settlement on a $\mathrm{T}+0$ basis. At the end of the auction market session, CCIL initiates auction matching based on the uniform yield principle.

- $\quad$ CCIL assumes the role of the central counterparty through the process of novation and guarantees settlement of transactions in CBLO.

- $\quad$ Automated value-free transfer of securities between market participants and the CCIL was introduced during 2004-05.

- $\quad$ Members can reckon unencumbered securities for SLR calculation purposes.

- $\quad$ The operations in CBLO are exempted from cash reserve requirements (CRR).

\section{Market repo}

- $\quad$ To broaden the repo market, the Reserve Bank enabled non-banking financial companies, mutual funds, housing finance companies and insurance companies not holding SGL accounts to undertake repo transactions with effect from March 3, 2003. 
These entities were permitted to access the repo market through their "gilt accounts" maintained with the custodians.

- $\quad$ Subsequently, non-scheduled urban co-operative banks and listed companies with gilt accounts with scheduled commercial banks were allowed to participate.

- $\quad$ Necessary precautions were built into the system to ensure delivery versus payment (DvP) and transparency, while restricting the repos to Government securities only.

- Rollover of repo transactions in Government securities was facilitated with the enabling of the DVP III mode of settlement in Government securities, which involves settlement of securities and funds on a net basis, effective April 2, 2004. This provided significant flexibility to market participants in managing their collateral.

\section{Some assessments}

- $\quad$ CBLO and market repo helped in aligning short-term money market rates to the LAF corridor.

- $\quad$ Mutual funds and insurance companies are generally the main supplier of funds while banks, primary dealers and corporates are the major borrowers in the repo market outside the LAF.BoxText 


\section{Annex III: \\ Reforms in government securities market institutional measures}

- $\quad$ Administered interest rates on government securities were replaced by an auction system for price discovery.

- $\quad$ Automatic monetization of the fiscal deficit through the issue of ad hoc Treasury Bills was phased out.

- $\quad$ Primary dealers (PD) were introduced as market makers in the government securities market.

- $\quad$ To ensure transparency in the trading of government securities, delivery versus payment (DvP) settlement was introduced.

- $\quad$ Repurchase agreements (repos) were introduced as a tool for short-term liquidity adjustment. Subsequently, the Liquidity Adjustment Facility (LAF) was introduced.

- $\quad$ LAF operates through repo and reverse repo auctions and provides a corridor for short-term interest rates. LAF has emerged both as the tool for liquidity management and as a signalling device for interest rates in the overnight market. The Second LAF (SLAF) was introduced in November 2005.

- A Market Stabilisation Scheme (MSS) has been introduced, which has expanded the instruments available to the Reserve Bank for managing the enduring surplus liquidity in the system.

- $\quad$ Effective April 1, 2006, RBI has withdrawn from participating in primary market auctions of Government paper.

- $\quad$ Banks have been permitted to undertake primary dealer business, while primary dealers are being allowed to diversify their business.

- $\quad$ Short sales in Government securities are being permitted in a calibrated manner, while guidelines for the "when issued" market have been issued recently.

\section{Increase in instruments in the government securities market}

- A 91-day Treasury Bill was introduced for managing liquidity and benchmarking. Zero Coupon Bonds, Floating Rate Bonds, and Capital Indexed Bonds were issued and exchange traded interest rate futures were introduced. OTC interest rate derivatives like IRS/FRAs were introduced.

- $\quad$ Outright sales of Central Government dated securities that are not owned have been permitted, subject to them being covered by outright purchases from the secondary market within the same trading day subject to certain conditions.

- $\quad$ Repo status has been granted to State Government securities in order to improve secondary market liquidity. 


\section{Enabling measures}

- $\quad$ Foreign Institutional Investors (FIIs) were allowed to invest in government securities subject to certain limits.

- Introduction of automated screen-based trading in government securities through Negotiated Dealing System (NDS).

- $\quad$ Setting up of a risk-free payment and settlement system in government securities through the Clearing Corporation of India Limited (CCIL).

- $\quad$ Phased introduction of Real Time Gross Settlement System (RTGS).

- Introduction of trading in Government securities on stock exchanges for promoting retailing in such securities, permitting non-banks to participate in the repo market.

- $\quad$ Recent measures include the introduction of NDS-OM and T + 1 settlement norms. 


\section{Annex IV: \\ Reforms in the foreign exchange market}

\section{Exchange rate regime}

- $\quad$ Evolution of the exchange rate regime from a single-currency fixed exchange rate system to fixing the value of rupee against a basket of currencies and further to a market-determined floating exchange rate regime.

- $\quad$ Adoption of convertibility of the rupee for current account transactions with acceptance of Article VIII of the Articles of Agreement of the IMF. De facto full capital account convertibility for non-residents and calibrated liberalization of transactions undertaken for capital account purposes in the case of residents.

\section{Institutional framework}

- $\quad$ Replacement of the earlier Foreign Exchange Regulation Act (FERA), 1973 by the market friendly Foreign Exchange Management Act, 1999. Delegation of considerable powers by the RBI to authorised dealers to release foreign exchange for a variety of purposes.

\section{Increase in instruments in the foreign exchange market}

- $\quad$ Development of rupee-foreign currency swap market.

- Introduction of additional hedging instruments, such as foreign currency-rupee options. Authorised dealers permitted to use innovative products like cross-currency options, interest rate swaps (IRS) and currency swaps, caps/collars and forward rate agreements (FRAs) in the international forex market.

\section{Liberalization measures}

- $\quad$ Authorised dealers permitted to initiate trading positions, borrow and invest in the overseas market subject to certain specifications and ratification by the respective banks' boards. Banks are also permitted to fix interest rates on non-resident deposits, subject to certain specifications, use derivative products for asset-liability management and fix overnight open position limits and gap limits in the foreign exchange market, subject to ratification by the RBI.

- $\quad$ Permission for various participants in the foreign exchange market, including exporters, Indians investing abroad, Flls, to avail themselves forward cover and enter into swap transactions without any limit subject to genuine underlying exposure.

- $\quad$ FIIs and NRIs permitted to trade in exchange-traded derivative contracts subject to certain conditions. 
- $\quad$ Foreign exchange earners permitted to retain up to 100 per cent of their foreign exchange earnings in their Exchange Earners' Foreign Currency accounts. Residents are permitted to remit up to US\$50,000 per financial year.

- $\quad$ Authorised dealer banks may borrow funds from their overseas branches and correspondent banks (including borrowing for export credit, external commercial borrowings (ECBs) and overdrafts from their Head Office/Nostro account) up to a limit of 50 per cent of their unimpaired Tier I capital or US\$10 million, whichever is higher.

- $\quad$ Borrowers eligible for accessing ECBs can obtain an additional US\$250 million with average maturity of more than 10 years under the approval route. Prepayment of ECB up to US\$300 million without prior approval of the Reserve Bank.

- $\quad$ The existing limit of US\$2 billion on investments in Government securities by foreign institutional investors (FIIs) to be enhanced in phases to US $\$ 32$ billion by March 31, 2007.

- $\quad$ The extant ceiling of overseas investment by mutual funds of US\$2 2billion is enhanced to US\$3 billion.

- Importers to be permitted to book forward contracts for the customs duty component of imports.

- $\quad$ Flls to be allowed to rebook a part of the cancelled forward contracts.

- $\quad$ Forward contracts booked by exporters and importers in excess of 50 per cent of the eligible limit to be on deliverable basis and cannot be cancelled.

- $\quad$ Authorised dealer banks to be permitted to issue guarantees/letters of credit for import of services up to US\$100,000 for securing a direct contractual liability arising out of a contract between a resident and a non-resident.

- $\quad$ Lock-in period for sale proceeds of the immovable property credited to the NRO account to be eliminated, provided the amount being remitted in any financial year does not exceed US\$1 million. 


\section{Annex V: \\ Reforms in the banking sector}

\section{Competition enhancing measures}

- Granting of operational autonomy to public sector banks, reduction of public ownership in public sector banks by allowing them to raise capital from the equity market up to 49 per cent of paid-up capital.

- $\quad$ Transparent norms for entry of Indian private sector, foreign and joint-venture banks and insurance companies, permission for foreign investment in the financial sector in the form of foreign direct investment (FDI) as well as portfolio investment, permission for banks to diversify product portfolio and business activities.

- $\quad$ Roadmap for presence of foreign banks and guidelines for mergers and amalgamation of private sector banks and banks and NBFCs.

- $\quad$ Guidelines on ownership and governance in private sector banks.

\section{Measures enhancing role of market forces}

- $\quad$ Sharp reduction in pre-emption through reserve requirements, market-determined pricing for government securities, removal of administered interest rates with a few exceptions, and enhanced transparency and disclosure norms to facilitate market discipline.

- Introduction of a pure inter-bank call money market, auction-based repos-reverse repos for short-term liquidity management, facilitation of an improved payment and settlement mechanism.

- $\quad$ Significant advance in dematerialization; markets for securitised assets are being developed.

\section{Prudential measures}

- Introduction and phased implementation of international best practices and norms on risk-weighted capital adequacy requirements, accounting, income recognition, provisioning and exposure.

- Measures to strengthen risk management through recognition of different components of risk, assignment of risk weights to various asset classes, norms on connected lending, risk concentration, application of marked-to-market principle for investment portfolio and limits on deployment of funds in sensitive activities.

- $\quad$ "Know Your Customer" and "Anti-Money Laundering" guidelines, roadmap for Basel II, introduction of capital charge for market risk, higher graded provisioning for NPAs, guidelines for ownership and governance, securitization and debt restructuring mechanisms norms, etc. 


\section{Institutional and legal measures}

- $\quad$ Setting up of Lok Adalats (people's courts), debt recovery tribunals, asset reconstruction companies, settlement advisory committees, corporate debt restructuring mechanisms, etc. for quicker recovery/restructuring.

- $\quad$ Promulgation of Securitisation and Reconstruction of Financial Assets and Enforcement of Securities Interest (SARFAESI) Act, 2002 and its subsequent amendment to ensure creditor rights.

- $\quad$ Setting up of Credit Information Bureau of India Limited (CIBIL) for information sharing on defaulters as well as other borrowers.

- $\quad$ Setting up of Clearing Corporation of India Limited (CCIL) to act as central counterparty for facilitating transactions through the payment and settlement system relating to fixed income securities and money market instruments.

\section{Supervisory measures}

- $\quad$ Establishment of the Board for Financial Supervision as the supreme supervisory authority for commercial banks, financial institutions and non-banking financial companies.

- Introduction of the CAMELS supervisory rating system, move towards risk-based supervision, consolidated supervision of financial conglomerates, strengthening of off-site surveillance through control returns.

- $\quad$ Recasting of the role of statutory auditors, increased internal control through strengthening of internal audit.

- $\quad$ Strengthening corporate governance, enhanced due diligence on important shareholders, fit and proper tests for directors.

\section{Technology-related measures}

- $\quad$ Setting up of INFINET as the communication backbone for the financial sector; introduction of Negotiated Dealing System (NDS) for screen-based trading in Government securities and Real Time Gross Settlement (RTGS) System. 


\section{Annex VI: Liquidity adjustment facility}

- $\quad$ As part of the financial sector reforms launched in mid-1991, India began to move away from direct instruments of monetary control to indirect ones. A transition of this kind involves considerable efforts to develop markets, institutions and practices. In order to facilitate such transition, India developed a Liquidity Adjustment Facility (LAF) in phases considering country-specific features of the Indian financial system. LAF is based on repo/reverse repo operations by the central bank.

- $\quad$ In 1998 the Committee on Banking Sector Reforms (Narasimham Committee II) recommended the introduction of a Liquidity Adjustment Facility (LAF) under which the Reserve Bank would conduct auctions periodically, if not necessarily daily. The Reserve Bank could reset its repo and reverse repo rates, which would in a sense provide a reasonable corridor for the call money market. In pursuance of these recommendations, a major change in the operating procedure became possible in April 1999 through the introduction of an Interim Liquidity Adjustment Facility (ILAF), under which repos and reverse repos were formalised. With the introduction of ILAF, the general refinance facility was withdrawn and replaced by a collateralised lending facility (CLF) up to 0.25 per cent of the fortnightly average outstanding of aggregate deposits in 1997-98 for two weeks at the bank rate. An additional collateralised lending facility (ACLF) for an equivalent amount of CLF was made available at the Bank Rate plus 2 per cent. CLF and ACLF taken out for periods beyond two weeks were subjected to a penalty rate of 2 per cent for an additional two-week period. Export credit refinance for scheduled commercial banks was retained and continued to be provided at the bank rate. Liquidity support to PDs against collateral of Government securities at the bank rate was also provided for. ILAF was expected to promote money market stability and ensure that the interest rates moved within a reasonable range.

- $\quad$ The transition from ILAF to a full-fledged LAF began in June 2000 and was undertaken in three stages. In the first stage, beginning June 5, 2000, LAF was formally introduced and the Additional CLF and level II support to PDs was replaced by variable rate repo auctions with same day settlement. In the second stage, beginning May 2001, CLF and level I liquidity support for banks and PDs was also replaced by variable rate repo auctions. Some minimum liquidity support to PDs was continued but at an interest rate linked to the variable rate in the daily repo auctions as determined by the RBI from time to time. In April 2003, the multiplicity of rates at which liquidity was being absorbed/injected under the back-stop facility was rationalised and the back-stop interest rate was fixed at the reverse repo cut-off rate at the regular LAF auctions on that day. If there was no reverse repo in the LAF auctions, the back-stop rate was fixed at 2.0 percentage points above the repo cutoff rate. It was also announced that on days when no repo/reverse repo bids were received/accepted, the back-stop rate would be decided by the Reserve Bank on an ad-hoc basis. A revised LAF scheme was operationalised effective March 29, 2004, under which the reverse repo rate was reduced to 6.0 per cent and aligned with the bank rate. The normal facility and the backstop facility were merged into a single facility and made available at a single rate. The third stage of full-fledged LAF had begun with the full computerization of the Public Debt Office (PDO), and the introduction of RTGS marked a big step forward in this phase. Repo operations today are mainly through electronic transfers. Fixed rate auctions have been reintroduced since April 2004. The possibility of operating LAF at different times on the same day is now close to being materialised. In that sense we have very nearly completed the transition to a full-fledged LAF. 
- $\quad$ With the introduction of the Second LAF (SLAF) from November 28, 2005 market participants now have a second window to fine-tune the management of liquidity. In the past, LAF operations were conducted between 9.30 a.m. and 10.30 a.m. SLAF is conducted by receiving bids between 3.00 p.m. and 3.45 p.m. The salient features of SLAF are the same as those of LAF and the settlement for both is conducted separately and on a gross basis. The introduction of LAF has been a gradual process and the Indian experience shows that a phased rather than big bang approach is required for reforms in the financial sector and in monetary management.

\section{References:}

Reserve Bank of India (1999), Repurchase Agreements (Repos): Report of the Sub-group of the Technical Advisory Committee on Government Securities Market, April, 1999, Mumbai. Mumbai.

(2003), Report of the Internal Group on Liquidity Adjustment Facility, December 2003, 


\section{Annex VII: \\ Market stabilisation scheme (MSS)}

- $\quad$ The money markets have operated in liquidity surplus mode since 2002 due to large capital inflows and current account surplus. The initial burden of sterilization was borne by the outright transaction of dated securities and T-bills. However, due to the depletion in stock of government securities, the burden of liquidity adjustment shifted to LAF, which is essentially a tool for marginal liquidity adjustment. Keeping in view the objective of absorbing the liquidity of enduring nature using instruments other than LAF, the Reserve Bank appointed a Working Group on Instruments of Sterilisation (Chairperson: Smt Usha Thorat). The Group recommended the issuance of T-bills and dated securities under the Market Stabilisation Scheme (MSS), with the proceeds of MSS being held by the Government in a separate identifiable cash account maintained and operated by the RBI. The amounts credited into the MSS Account would be appropriated only for the purpose of redemption and/or buy back of the Treasury Bills and/or dated securities issued under the MSS. In pursuance of the recommendation, the Government of India and $\mathrm{RBI}$ signed a Memorandum of Understanding (MoU) on March 25, 2004. As part of the MoU, the scheme was made operational in April 2004. It was agreed that the Government would issue Treasury Bills and/or dated securities under the MSS in addition to the normal borrowing requirements, for absorbing liquidity from the system. These securities would be issued by way of auctions by the Reserve Bank and the instruments would have all the attributes of existing T-bills and dated securities. They were to be serviced like any other marketable government securities. MSS securities are treated as eligible securities for the Statutory Liquidity Ratio (SLR), repos and the Liquidity Adjustment Facility (LAF).

- $\quad$ The proceeds of the MSS are held by the Government in a separate identifiable cash account maintained and operated by the Reserve Bank. The amount held in this account is appropriated only for the purpose of redemption and/or buyback of the Treasury Bills and/or dated securities issued under the MSS. The payments for interest and discount on MSS securities are not made from the MSS account. The receipts due to premium and/or accrued interest are also not credited to the MSS account. Such receipts and payments towards interest, premium and discount are shown in the budget and other related documents as distinct components under separate sub-headings. Thus, they only have a marginal impact on the revenue and fiscal balances of the Government to the extent of interest payment on the outstanding under the MSS.

- $\quad$ For mopping up enduring surplus liquidity, a policy choice exists between the central bank issuing its own securities or the Government issuing additional securities. A large number of countries, such as Chile, China, Colombia, Indonesia, Korea, Malaysia, Peru, the Philippines, Russia, Sri Lanka, Tawian and Thailand, have issued central bank securities. However, central banks of many of these countries faced deterioration in their balance sheets. As such, there are merits in issuing sterilization bonds on the government account. This is more so in the case of an already well established government debt market, where the issuance of new central bank bills of overlapping maturity could cause considerable confusion and possible market segmentation which could obfuscate the yield curve, reduce liquidity of the instruments and make operations that much more difficult.

- $\quad$ MSS has considerably strengthened the Reserve Bank's ability to conduct exchange rate and monetary management operations. It has allowed absorption of surplus liquidity by instruments of short-term (91-day, 182-day and 364-day T-bills) and 
medium-term (dated Government securities) maturity. Generally, the preference has been for the short-term instruments. This has given the monetary authorities a greater degree of freedom in liquidity management during transitions in the liquidity situation.

\section{Reference:}

Reserve Bank of India (2003), Report of the Working Group on Instruments of Sterlisation, Mumbai, December. 


\section{Annex VIII: Liquidity management during IMD redemption}

- $\quad$ The India Millennium Deposits (IMDs) were foreign currency denominated deposits issued by the State Bank of India in 2000, on the advice of the Government of India. It mobilised a sum of USD 5.5 billion for a tenor of five years. IMD carried coupons of 8.50 per cent, 7.85 per cent and 6.85 per cent on US dollar, Pound Sterling and Euro denominated deposits respectively. IMD subscription was limited to nonresident Indians, persons of Indian origin and overseas corporate bodies. The interest income earned on IMD was exempted from tax and there was provision for premature encashment after six months only in non-repatriable Indian rupees. These IMDs matured on December 28-29, 2005 and the large sums involved presented a challenge for liquidity management.

- $\quad$ Liquidity management in the face of IMD redemptions was carried out to contain disequilibrium while retaining a monetary policy stance with a medium-term objective. Outflows on account of the redemptions were met by smoothing arrangements worked out for that purpose. During December 27-29, 2005, the RBI sold foreign exchange out of its foreign exchange reserves to the State Bank of India (SBI) totaling nearly US\$ 7.1 billion, which in rupee equivalent terms was about Rs.32,000 crore. SBI, for its part, had built up the necessary rupee resources to meet the obligations. Temporary tightness in liquidity was met by releasing liquidity through the repo window (including the second LAF), averaging about Rs.23,000 crore per day in the last week of December, coinciding with the IMD redemptions, outflows due to advance tax payments and the continued surge in credit offtake. The second LAF window made available since November 28, 2005 provided an additional opportunity for market participants to fine tune their liquidity management. The smooth redemption of the IMD liability of this size, bunched at a point of time, reflects the growing maturity of the financial markets and the strength of the liquidity management system that has been put in place. Short-term money market rates eased remarkably in the first week of January 2006, reflecting smooth redemptions of IMDs, but firmed up in the second week, reflecting pressures emanating from scheduled auctions of Government securities.

Source: Mohan (2006a) 


\section{Annex IX: \\ Prudential guidelines impacting monetary transmission in India}

The Reserve Bank has issued several prudential capital requirement and supervisory guidelines which could have an impact on the transmission of monetary policy in India. These include:

- $\quad$ For ensuring a smooth transition to Basel II norms, banks were required to maintain a capital charge for market risk on their trading book exposures (including derivatives) by March 31, 2005 and on the securities included under the Available for Sale category by March 31, 2006.

- $\quad$ Banks in India have been advised to adopt the Standardised Approach for credit risk and Basic Indicator Approach for operational risk under the New Capital Adequacy Framework with effect from March 31, 2008.

- $\quad$ Effective March 31, 2002, banks were permitted to have single or group borrower credit exposure up to 15 per cent and 40 per cent of their capital funds (Tier I and Tier II capital) respectively, with an additional allowance of 5 per cent and 10 per cent of their capital funds for the infrastructure sector. In May 2004 banks were permitted to consider enhancement of their exposure to the borrower up to a further 5 per cent of capital funds, subject to the banks disclosing this in their annual reports.

- $\quad$ Banks' aggregate exposure to the capital market was restricted to 40 per cent of their net worth on a solo and consolidated basis. The consolidated direct capital market exposure was restricted to 20 per cent of banks' consolidated net worth.

- $\quad$ The RBI issued a "Guidance Note on Management of Operational Risk" in October 2005 to enable the banks to have a smooth transition to the New Capital Adequacy Framework. Banks using the Basic Indicator Approach were encouraged to comply with "Sound Practices for the Management and Supervision of Operational Risk" issued by the Basel Committee on Banking Supervision in February 2003.

- In order to encourage banks' early compliance with the guidelines for maintenance of a capital charge for market risks, banks were advised in April 2005 that banks which have maintained capital of at least 9 per cent of the risk-weighted assets for both credit risk and market risks for both the Held For Trading (HFT) and the Available For Sale (AFS) categories may treat the balance in excess of 5 per cent of securities included under HFT and AFS categories, in the Investment Fluctuation Reserves (IFR), as Tier I capital.

- In view of strong growth of housing and consumer credit, risk containment measures were put in place and the risk weights were increased in October 2004 from 50 per cent to 75 per cent in the case of housing loans and from 100 per cent to 125 per cent in the case of consumer credit including personal loans and credit cards. The risk weight on banks' exposure to commercial real estate was increased from 100 per cent to 125 per cent in July 2005 and further to 150 per cent in April 2006.

- It was decided in April 2006 that bank's total exposure to venture capital funds will form a part of their capital market exposure and banks should, henceforth, assign a higher risk weight of 150 per cent to these exposures.

- Taking into account the trends in credit growth, the general provisioning requirement for "standard advances" was increased in October 2005 from 0.25 per cent to 0.40 per cent. Banks' direct advances to the agricultural and SME sectors were 
exempted from the additional provisioning requirement. In April 2006, the RBI further increased the general provisioning requirement on standard advances in specific sectors, ie, personal loans, loans and advances qualifying as capital market exposures, residential housing loans beyond Rs.20 lakh and commercial real estate loans, from the existing level of 0.40 per cent to 1.0 per cent. These provisions are eligible for inclusion in Tier II capital for capital adequacy purposes up to the permitted ceiling.

- With regard to trends in the credit markets, a supervisory review process was initiated with select banks having significant exposure to some sectors, namely, real estate, highly leveraged NBFCs, venture capital funds and capital markets, in order to ensure that effective risk mitigants and sound internal controls are in place for managing such exposures.

- In October 2005, the RBI restricted banks' aggregate exposure to the capital market to 40 per cent of their net worth on a solo and consolidated basis. The consolidated direct capital market exposure has been restricted to 20 per cent of banks' consolidated net worth.

- In January 2007, the provisioning requirement was increased to 2 per cent for standard assets in the real estate sector, outstanding credit card receivables, loans and advances qualifying as capital market exposure and personal loans (excluding residential housing loans); the provisioning requirement was also increased to 2 per cent for banks' exposures in the standard assets category to the non-deposit-taking systemically important non-banking financial companies (NBFCs); the risk weight was increased to 125 per cent for banks' exposure to non-deposit-taking systemically important NBFCs. 


\section{Annex X: \\ The evolving stance of monetary policy in India}

\section{Highlights}

- $\quad$ The statement on the stance of monetary policy was introduced from the policy statement of April 1996.

- $\quad$ The emphasis on price stability and provision of credit to support growth has since run through the statements on stance.

- $\quad$ Exchange rate stability was underlined in the stance of April 1996.

- $\quad$ The pursuit of financial reforms, accelerated investment, improvement in credit delivery mechanisms particularly for agriculture and small and medium sectors, soft interest rate regime, interest rate signaling and liquidity management were included for the first time in the stance of April 1998.

- $\quad$ The role of active debt management was emphasized in the stance of April 1999.

- $\quad$ Ensuring financial stability came to be recognized from the stance of October 1999.

- $\quad$ Macroeconomic stability was emphasized in the stance of April 2004.

- $\quad$ The need for support to export demand, stabilization of inflation expectations and calibrated actions was underlined in the stance of October 2004.

- A prompt and effective response to the evolving situation was underlined in the stance of July 2005.

- $\quad$ The aspect of credit quality was emphasized in the stance of January 2006.

- A swift response to evolving global developments was promised in the stance of April 2006.

- $\quad$ Financial inclusion was emphasized, for the first time, in the stance of January 2007. 


\begin{tabular}{|c|c|c|}
\hline \multicolumn{3}{|c|}{ Details } \\
\hline Year & Annual policy & Mid term review \\
\hline 1996-97 & $\begin{array}{l}\text { Credit support to sustain growth and a } \\
\text { reasonable degree of price and exchange } \\
\text { rate stability. }\end{array}$ & $\begin{array}{l}\text { Price stability and adequate supply of } \\
\text { bank credit to the productive sectors of } \\
\text { the economy. }\end{array}$ \\
\hline 1997-98 & $\begin{array}{l}\text { Maintaining reasonable price stability and } \\
\text { ensuring availability of adequate bank } \\
\text { credit to support the growth of the real } \\
\text { sector. }\end{array}$ & $\begin{array}{l}\text { Promoting price stability and ensuring } \\
\text { availability of adequate bank credit to } \\
\text { meet the requirements of productive } \\
\text { sectors of the economy. }\end{array}$ \\
\hline 1998-99 & $\begin{array}{l}\text { Need to accelerate industrial investment } \\
\text { and output in the economy; maintenance } \\
\text { of low rates of inflation; continued pursuit } \\
\text { of financial reform; reduction in interest } \\
\text { rates; and improvement in credit delivery } \\
\text { mechanisms, particularly for agriculture } \\
\text { and medium and small sectors. }\end{array}$ & $\begin{array}{l}\text { Flexible use of interest rate instruments } \\
\text { to signal RBI's stance regarding } \\
\text { monetary conditions and management } \\
\text { of the flow of liquidity in the system. }\end{array}$ \\
\hline 1999-00 & $\begin{array}{l}\text { Provision of reasonable liquidity; stable } \\
\text { interest rates with policy preference for } \\
\text { softening to the extent circumstances } \\
\text { permit; active debt-management; orderly } \\
\text { development of financial markets; and } \\
\text { further steps in financial sector reforms. }\end{array}$ & $\begin{array}{l}\text { Provision of reasonable liquidity; stable } \\
\text { interest rates with preference for } \\
\text { softening to the extent possible within } \\
\text { the existing operational and structural } \\
\text { constraints; orderly development of } \\
\text { financial markets and ensuring financial } \\
\text { stability. }\end{array}$ \\
\hline 2000-01 & $\begin{array}{l}\text { Continue the current stance of monetary } \\
\text { policy and ensure that all legitimate } \\
\text { requirements for bank credit are met while } \\
\text { guarding against any emergence of } \\
\text { inflationary pressures due to excess } \\
\text { demand. }\end{array}$ & \\
\hline 2001-02 & $\begin{array}{l}\text { Provision of adequate liquidity to meet } \\
\text { credit growth and support revival of } \\
\text { investment demand while continuing a vigil } \\
\text { on movements in the price level. } \\
\text { Within the overall framework of imparting } \\
\text { greater flexibility to the interest rate regime } \\
\text { in the medium-term, to continue the } \\
\text { present stable interest rate environment } \\
\text { with a preference for softening to the } \\
\text { extent the evolving situation warrants. }\end{array}$ & \\
\hline 2002-03 & $\begin{array}{l}\text { Provision of adequate liquidity to meet } \\
\text { credit growth and support revival of } \\
\text { investment demand while continuing a vigil } \\
\text { on movements in the price level. } \\
\text { Within the overall framework of imparting } \\
\text { greater flexibility to the interest rate regime } \\
\text { in the medium-term, to continue the } \\
\text { present stable interest rate environment } \\
\text { with a preference for softening to the } \\
\text { extent the evolving situation warrants. }\end{array}$ & $\begin{array}{l}\text { Same as outlined in Annual Policy of } \\
\text { April } 2002 .\end{array}$ \\
\hline
\end{tabular}




\begin{tabular}{|c|c|c|}
\hline \multicolumn{3}{|c|}{ Details (cont) } \\
\hline Year & Annual policy & Mid term review \\
\hline 2003-04 & $\begin{array}{l}\text { Provision of adequate liquidity to meet } \\
\text { credit growth and support investment } \\
\text { demand in the economy while continuing a } \\
\text { vigil on movements in the price level. } \\
\text { In line with the above, to continue the } \\
\text { present stance on interest rates including } \\
\text { preference for soft interest rates. } \\
\text { To impart greater flexibility to the interest } \\
\text { rate structure in the medium-term. }\end{array}$ & $\begin{array}{l}\text { Same as outlined in Annual Policy of } \\
\text { April } 2003 .\end{array}$ \\
\hline 2004-05 & $\begin{array}{l}\text { Provision of adequate liquidity to meet } \\
\text { credit growth and support investment } \\
\text { demand in the economy while continuing a } \\
\text { vigil on movements in the price level. } \\
\text { In line with the above, to continue with the } \\
\text { present stance of preference for a soft and } \\
\text { flexible interest rate environment within the } \\
\text { framework of macroeconomic stability. }\end{array}$ & $\begin{array}{l}\text { Provision of appropriate liquidity to meet } \\
\text { credit growth and support investment } \\
\text { and export demand in the economy } \\
\text { while placing equal emphasis on price } \\
\text { stability. } \\
\text { Consistent with the above, to pursue an } \\
\text { interest rate environment that is } \\
\text { conducive to macroeconomic and price } \\
\text { stability, and maintaining the momentum } \\
\text { of growth. } \\
\text { To consider measures in a calibrated } \\
\text { manner, in response to evolving } \\
\text { circumstances with a view to stabilising } \\
\text { inflationary expectations. }\end{array}$ \\
\hline
\end{tabular}




\begin{tabular}{|c|c|c|c|c|}
\hline Year & Annual policy & $\begin{array}{l}\text { First quarter } \\
\text { review }\end{array}$ & Mid term review & $\begin{array}{l}\text { Third quarter } \\
\text { review }\end{array}$ \\
\hline 2005-06 & $\begin{array}{l}\text { Provision of } \\
\text { appropriate liquidity to } \\
\text { meet credit growth } \\
\text { and support } \\
\text { investment and export } \\
\text { demand in the } \\
\text { economy while placing } \\
\text { equal emphasis on } \\
\text { price stability. } \\
\text { Consistent with the } \\
\text { above, to pursue an } \\
\text { interest rate } \\
\text { environment that is } \\
\text { conducive to } \\
\text { macroeconomic and } \\
\text { price stability, and } \\
\text { maintaining the } \\
\text { momentum of growth. } \\
\text { To consider measures } \\
\text { in a calibrated } \\
\text { manner, in response } \\
\text { to evolving } \\
\text { circumstances with a } \\
\text { view to stabilising } \\
\text { inflationary } \\
\text { expectations. }\end{array}$ & $\begin{array}{l}\text { Same stance for } \\
\text { the remaining part } \\
\text { of the year as set } \\
\text { out in the annual } \\
\text { policy Statement } \\
\text { of April 2005, but } \\
\text { the Reserve Bank } \\
\text { would respond, } \\
\text { promptly and } \\
\text { effectively, to the } \\
\text { evolving situation } \\
\text { depending on the } \\
\text { unfolding of the } \\
\text { risks. }\end{array}$ & $\begin{array}{l}\text { Consistent with } \\
\text { emphasis on price } \\
\text { stability, provision } \\
\text { of appropriate } \\
\text { liquidity to meet } \\
\text { genuine credit } \\
\text { needs and support } \\
\text { export and } \\
\text { investment } \\
\text { demand in the } \\
\text { economy. } \\
\text { Ensuring an } \\
\text { interest rate } \\
\text { environment that } \\
\text { is conducive to } \\
\text { macroeconomic } \\
\text { and price stability, } \\
\text { and maintaining } \\
\text { the growth } \\
\text { momentum. } \\
\text { To consider } \\
\text { measures in a } \\
\text { calibrated and } \\
\text { prompt manner, in } \\
\text { response to } \\
\text { evolving } \\
\text { circumstances } \\
\text { with a view to } \\
\text { stabilising } \\
\text { inflationary } \\
\text { expectations. }\end{array}$ & $\begin{array}{l}\text { To maintain the } \\
\text { emphasis on price } \\
\text { stability with a } \\
\text { view to anchoring } \\
\text { inflationary } \\
\text { expectations. } \\
\text { To continue to } \\
\text { support export anc } \\
\text { investment } \\
\text { demand in the } \\
\text { economy for } \\
\text { maintaining the } \\
\text { growth momentum } \\
\text { by ensuring a } \\
\text { conducive interest } \\
\text { rate environment } \\
\text { for } \\
\text { macroeconomic, } \\
\text { price and financial } \\
\text { stability. } \\
\text { To provide } \\
\text { appropriate } \\
\text { liquidity to meet } \\
\text { genuine credit } \\
\text { needs of the } \\
\text { economy with due } \\
\text { emphasis on } \\
\text { quality. } \\
\text { To consider } \\
\text { responses as } \\
\text { appropriate to } \\
\text { evolving } \\
\text { circumstances. }\end{array}$ \\
\hline 2006-07 & $\begin{array}{l}\text { To ensure a monetary } \\
\text { and interest rate } \\
\text { environment that } \\
\text { enables continuation } \\
\text { of the growth } \\
\text { momentum consistent } \\
\text { with price stability } \\
\text { while being in } \\
\text { readiness to act in a } \\
\text { timely and prompt } \\
\text { manner on any signs } \\
\text { of evolving } \\
\text { circumstances } \\
\text { impinging on inflation } \\
\text { expectations. } \\
\text { To focus on credit } \\
\text { quality and financial } \\
\text { market conditions to } \\
\text { support export and } \\
\text { investment demand in } \\
\text { the economy for }\end{array}$ & $\begin{array}{l}\text { To ensure a } \\
\text { monetary and } \\
\text { interest rate } \\
\text { environment that } \\
\text { enables } \\
\text { continuation of the } \\
\text { growth momentum } \\
\text { while emphasizing } \\
\text { price stability with } \\
\text { a view to } \\
\text { anchoring inflation } \\
\text { expectations. } \\
\text { To reinforce the } \\
\text { focus on credit } \\
\text { quality and } \\
\text { financial market } \\
\text { conditions to } \\
\text { support export and } \\
\text { investment } \\
\text { demand in the } \\
\text { economy for }\end{array}$ & $\begin{array}{l}\text { To ensure a } \\
\text { monetary and } \\
\text { interest rate } \\
\text { environment that } \\
\text { supports export } \\
\text { and investment } \\
\text { demand in the } \\
\text { economy so as to } \\
\text { enable } \\
\text { continuation of the } \\
\text { growth momentum } \\
\text { while reinforcing } \\
\text { price stability with } \\
\text { a view to } \\
\text { anchoring inflation } \\
\text { expectations. } \\
\text { To maintain the } \\
\text { emphasis on } \\
\text { macroeconomic } \\
\text { and, in particular, } \\
\text { financial stability. }\end{array}$ & $\begin{array}{l}\text { To reinforce the } \\
\text { emphasis on price } \\
\text { stability and well } \\
\text { anchored inflation } \\
\text { expectations while } \\
\text { ensuring a } \\
\text { monetary and } \\
\text { interest rate } \\
\text { environment that } \\
\text { supports export } \\
\text { and investment } \\
\text { demand in the } \\
\text { economy so as to } \\
\text { enable } \\
\text { continuation of the } \\
\text { growth } \\
\text { momentum. } \\
\text { To re-emphasise } \\
\text { credit quality and } \\
\text { orderly conditions } \\
\text { in financial }\end{array}$ \\
\hline
\end{tabular}




\begin{tabular}{|c|c|c|c|c|}
\hline Year & Annual policy & $\begin{array}{l}\text { First quarter } \\
\text { review }\end{array}$ & Mid term review & $\begin{array}{l}\text { Third quarter } \\
\text { review }\end{array}$ \\
\hline $\begin{array}{l}2006-07 \\
\text { (cont) }\end{array}$ & $\begin{array}{l}\text { maintaining } \\
\text { macroeconomic, in } \\
\text { particular, financial } \\
\text { stability. } \\
\text { To respond swiftly to } \\
\text { evolving global } \\
\text { developments. }\end{array}$ & $\begin{array}{l}\text { maintaining } \\
\text { macroeconomic } \\
\text { and, in particular, } \\
\text { financial stability. } \\
\text { To consider } \\
\text { measures as } \\
\text { appropriate to the } \\
\text { evolving global } \\
\text { and domestic } \\
\text { circumstances } \\
\text { impinging on } \\
\text { inflation } \\
\text { expectations and } \\
\text { the growth } \\
\text { momentum. }\end{array}$ & $\begin{array}{l}\text { To consider } \\
\text { promptly all } \\
\text { possible measures } \\
\text { as appropriate to } \\
\text { the evolving global } \\
\text { and domestic } \\
\text { situation. }\end{array}$ & $\begin{array}{l}\text { markets for } \\
\text { securing } \\
\text { macroeconomic } \\
\text { and, in particular, } \\
\text { financial stability } \\
\text { while } \\
\text { simultaneously } \\
\text { pursuing greater } \\
\text { credit penetration } \\
\text { and financial } \\
\text { inclusion. } \\
\text { To respond swiftly } \\
\text { with all possible } \\
\text { measures as } \\
\text { appropriate to the } \\
\text { evolving global } \\
\text { and domestic } \\
\text { situation impinging } \\
\text { on inflation } \\
\text { expectations and } \\
\text { the growth } \\
\text { momentum. }\end{array}$ \\
\hline
\end{tabular}




\section{References}

Bernanke, B and M Gertler (1995): "Inside the black box: the credit channel of monetary policy transmission", Journal of Economic Perspectives, 9 (4).

Greenspan, A (2005): Testimony before the Committee on Banking, Housing, and Urban Affairs, US Senate, February 16.

Mohan, R (2004): "Orderly global economic recovery: Are exchange rate adjustments effective any more?", Reserve Bank of India Bulletin, April.

- (2005): "Communications in central banks: A perspective", Reserve Bank of India Bulletin, October.

(2006a): "Coping with liquidity management in India: Practitioner's view", Reserve Bank of India Bulletin, April.

- (2006b): "Evolution of central banking in India", Reserve Bank of India Bulletin, June.

- (2006c): "Monetary policy and exchange rate frameworks: The Indian experience", Reserve Bank of India Bulletin, June.

Nag, A and A Das (2002): "Credit growth and response to capital requirements: Evidence from Indian public sector banks", Economic and Political Weekly, August 10.

Pandit, B, A Mittal, M Roy and S Ghosh (2006): "Transmission of monetary policy and the bank lending channel: Analysis and evidence for India", Development Research Group Study no 25, Reserve Bank of India.

Poole, W (1970): "Optimal choice of monetary policy instrument in a simple stochastic macro model", Quarterly Journal of Economics, 84 (2), May, 197-216.

Reserve Bank of India (2001): Report of the Expert Committee to Review the System of Administered Interest Rates and Other Related Issues (Chairman: Y V Reddy), September.

- (2002): Report on Currency and Finance 2000-01, January, Mumbai.

- (2004a): Report of the Advisory Committee to Advise on the Administered Interest Rates and Rationalisation of Saving Instruments (Chairman: Dr. Rakesh Mohan), RBI, July.

- (2004b): Report on Currency and Finance, 2003-04, December.

(2006): Annual Policy Statement for 2006-07, April.

Reddy, Y (2001): "Communications policy of the Reserve Bank of India", Reserve Bank of India Bulletin, September.

- (2006): "Central bank communications: Some random thoughts", Reserve Bank of India Bulletin, January. 